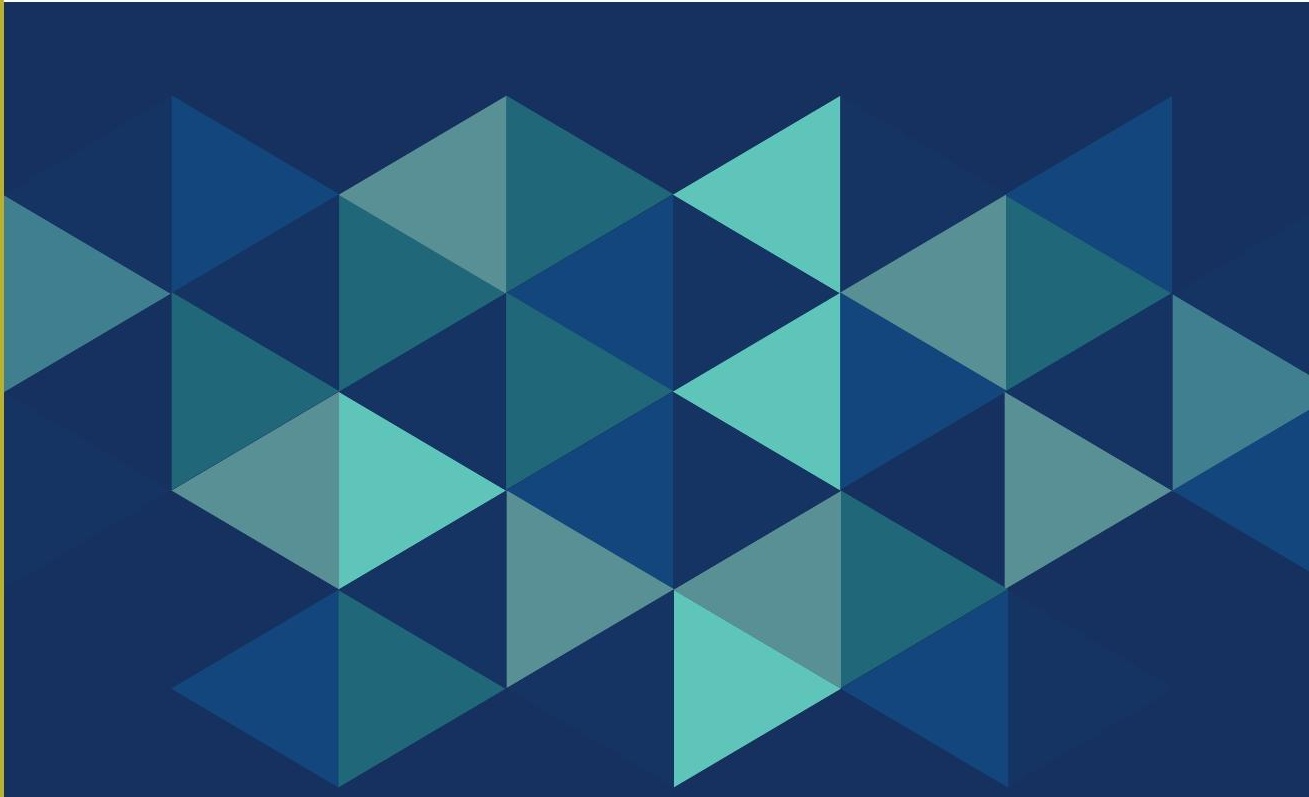

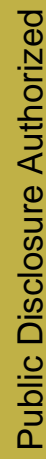

\title{
The Minimum Core of the Human Right to Health
}

Professor John Tasioulas
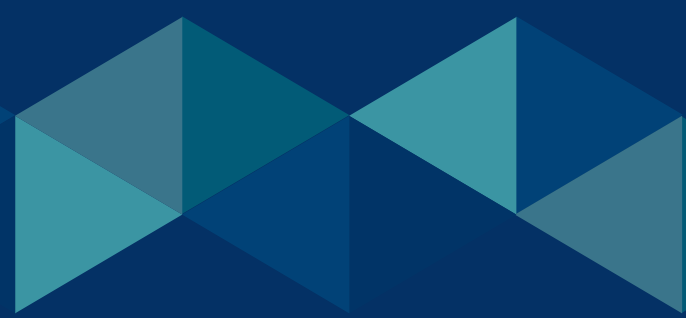



\section{The Minimum Core of the Human Right to Health}

Professor John Tasioulas

Research Paper | October 2017

Commissioned by the Nordic Trust Fund

The World Bank 
Disclaimer: The findings, interpretations, and conclusions expressed in this study are entirely those of the authors. They do not necessarily represent the views of the World Bank and its affiliated organizations, or those of the Executive Directors of the World Bank or the governments they represent. 


\section{Contents}

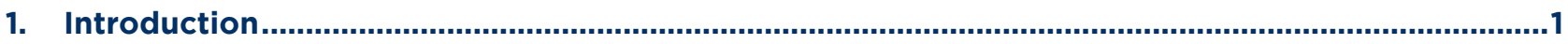

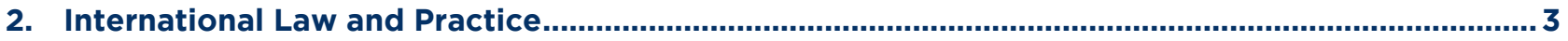

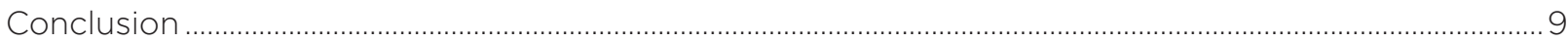

3. Regional Law and Practice ........................................................................................................... 11

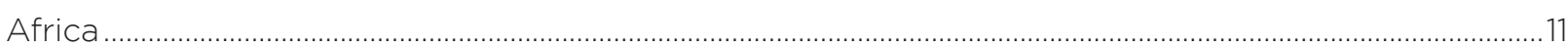

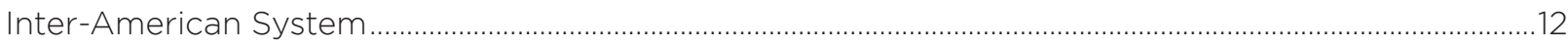

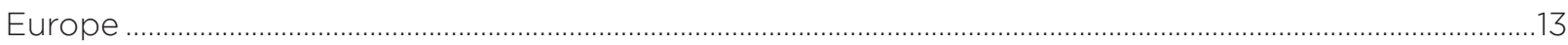

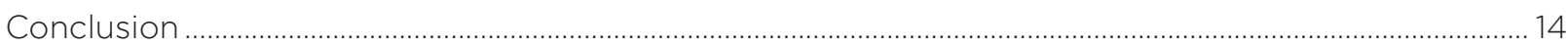

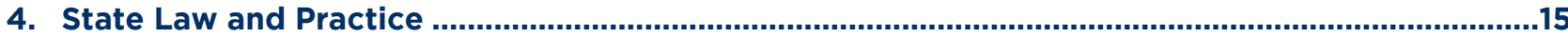

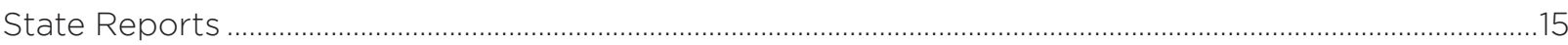

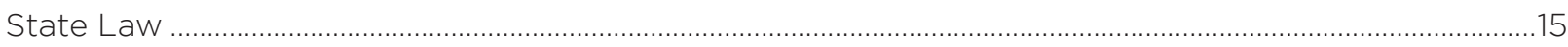

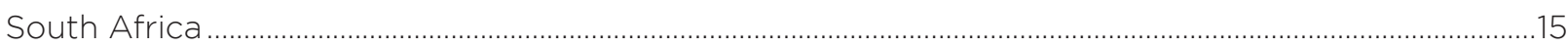

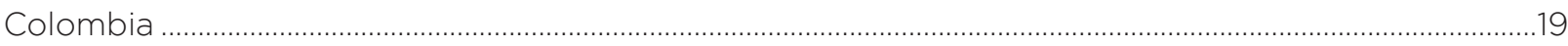

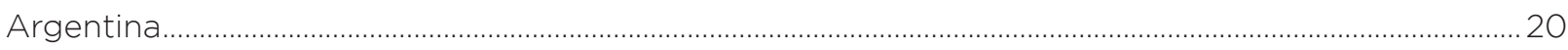

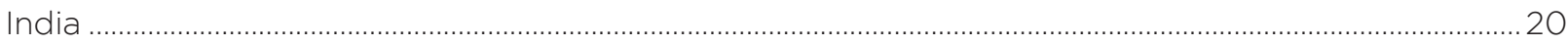

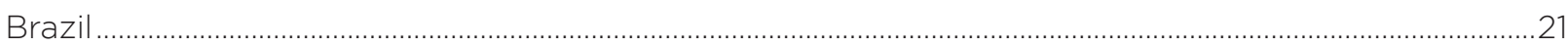

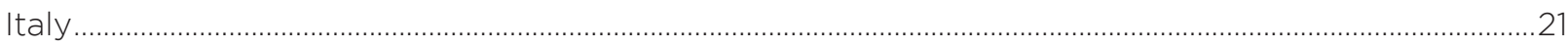

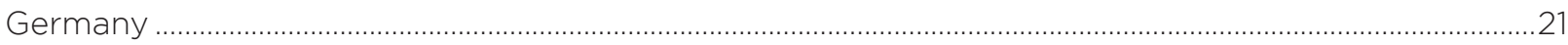

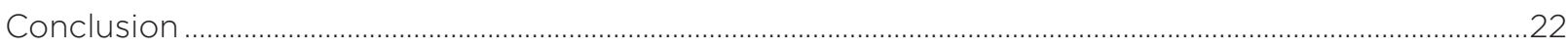

5. Minumum Core Obligations, Development, and Indicators …........................................................23

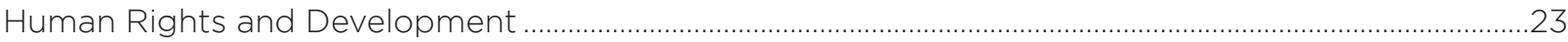

Universal Health Care and the Minimum Core of the Right to Health...................................................... 24

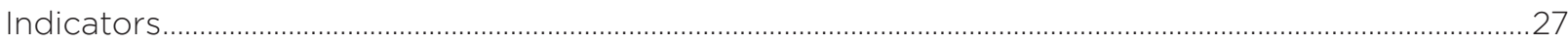


Nordic Trust Fund (NTF) is a knowledge and learning initiative to help the World Bank develop a more informed view on human rights. It is designed to improve existing Bank involvement on human rights in the overall context of the Bank's core mission of promoting economic growth and poverty reduction. The NTF is managed by a secretariat in the Operations Policy and Country Services vice-presidency (OPCS). Financial and staff support for the NTF is provided by Denmark, Finland, Iceland, Norway, and Sweden, with additional funding provided by Germany. 


\section{Introduction}

\footnotetext{
This This Report offers a critical interpretation of the idea of 'minimum core obligations' associated with the right to health in international, regional and domestic law and practice. Two important methodological complexities affecting this project need to be highlighted from the very outset.
}

First, it cannot be assumed that all uses of expressions such as 'the human right to health', 'the right to health', or 'minimum core obligations' bear the same meaning. This is especially so when we move across the international, regional and domestic domains. Instead, these phrases may mean significantly different things both within and across distinct jurisdictions. The relationship between international human rights law (IHRL) and the constitutional rights recognised by any given state, for example, is a complex one. In the case of many states, the norms of IHRL, even in the case of a treaty to which a state is party, do not automatically have domestic legal effect. Nor can it be assumed that when a state's constitution enshrines a right to health, the purpose of such a right is simply to implement domestically the human right to health in IHRL. The potential discrepancy between IHRL and constitutional law should not be surprising: IHRL are intended to give legal recognition and effect to moral rights we possess simply as human beings, whereas constitutional rights are organized around the idea of rights we ought to possess as citizens of a given polity. These are two distinct concepts, and they may pick out different rights or, where the name of the right is the same (e.g. a right to health), the content of the right may permissibly differ as between the two legal orders. It therefore follows that we cannot assume that the minimum core doctrine in relation to $\mathrm{IHRL}$ is equivalent, in meaning or normative content, to anything described by the same phrase in any regional or domestic jurisdiction.
Second, in seeking to identify the role played by the idea of minimum core obligations in the law and practice relating to the right to health in various jurisdictions, we must distinguish the concept of such obligations from the use of the words 'minimum core obligations'. Our main interest is in the former, rather than the latter, and it may be that the concept of a minimum core obligation plays an important role even when it is not explicitly referred to in those terms. For the purposes of this report, the essence of the concept will be taken to be the sub-set of obligations associated with socio-economic rights that must be immediately complied with in full (obligations of 'immediate effect'), and hence to which the doctrine of progressive realization is inapplicable. As argued in the Framework Report, a number of other characteristics are often associated with the idea of minimum core obligations - a connection to a special value, non-derogability and justiciability - but in line with the analysis recommended in that report, it is the idea of obligations of immediate effect that will be our primary focus. It follows that we will need to be on the look-out for jurisdictions that respond to the problem of resource scarcity by admitting some doctrine of 'progressive realization' regarding the obligations associated with economic, social or cultural rights, but that go on to treat a sub-set of these obligations as setting a limit to the operation of this doctrine, because they are to be complied with immediately. It is likely, in view of this interpretation of the doctrine, that the most fertile ground for investigating the minimum core concept 
will be those jurisdictions that recognize socio-economic rights but which confront acute problems of resource scarcity in complying with them. This gives a particular salience to the jurisprudence on the right to health in African and Latin American regional and domestic contexts.

The structure of this report is as follows. In Part II the idea of minimum core obligations corresponding to the right to health is examined as it manifests itself in international law and practice. Parts II and III consider how the same doctrine manifests itself in the context of regional legal orders (II) and state law and practice (III). Given the enormous volume of material potentially relevant here, these latter two parts are necessarily highly selective, with a focus on some of the most fertile cases for grasping the bearing on the minimum core doctrine on the right to health. Finally, in Part IV, the potential role of the minimum core obligations with respect to the right to health are highlighted with respect to development, focussing in particular on their bearing on the Sustainable Development Goals, priority-setting more generally, and the use of indicators. 


\section{International Law and Practice}

A key point of origin of the human right to health in the contemporary international legal order is the Constitution of the World Health Organization (WHO) (1946), whose preamble states:

Health is a state of complete physical, mental and social well-being and not merely the absence of disease or infirmity. The enjoyment of the highest attainable standard of health is one of the fundamental rights of every human being without distinction of race, religion, political belief, economic or social condition. ${ }^{1}$

Two years later, a reference to a right to health was incorporated in the foundational text of the international human rights order, the Universal Declaration of Human Rights (UDHR), Article 25:

Everyone has the right to a standard of living adequate for the health and wellbeing of himself and of his family, including food, clothing, housing and medical care and necessary social services, and the right to security in the event of unemployment, sickness, disability, widowhood, old age or other lack of livelihood in circumstances beyond his control'.2

Most importantly of all, however, the human right to health is affirmed in Article 12 of the International Covenant on Economic, Social and Cultural Rights (ICESCR). It provides:

1. The States Parties to the present Covenant recognize the right of everyone to the enjoyment of the highest attainable standard of physical and mental health.

2. The steps to be taken by the States Parties to the present Covenant to achieve the full realization of this right shall include those necessary for: (a) The provision for the reduction of the stillbirth-rate and of infant mortality and for the healthy development of the child;

(b) The improvement of all aspects of environmental and industrial hygiene;

(c) The prevention, treatment and control of epidemic, endemic, occupational and other diseases;

(d) The creation of conditions which would assure to all medical service and medical attention in the event of sickness. ${ }^{3}$

In addition, the human right to health - standardly, in the formulation of a 'right of everyone to the enjoyment of the highest attainable standard of physical and mental health' has been incorporated into a very large number of subsequent treaties and United National instruments. ${ }^{4}$

A genuine question arises as to which states are legally bound by the human right to health, especially as not all states

1 WHO Constitution 14 UNTS 185, adopted June/July 1946, entered into force April 7th, 1948.

2 Universal Declaration of Human Rights, GA Res 217A (III), UN Doc A/810 at 76 (1948)

3 International Covenant on Economic, Social and Cultural Rights, GA Res 2200 (XXI) A (UN Doc A/6316) at 49 (Dec. 16, 1966)

${ }^{4}$ UN world summits that reference the right to health include the Vienna Declaration and Programme of Action, adopted by the World Conference on Human Rights (Vienna), 14-15 June, 1993, esp. paras. 11, 18, 24, 31, and 41; the Programme of Action of the United Nations International Conference on Population and Development; and the Declaration and Programme of Action of the Fourth World Conference on Women. Three of the eight UN Millenium Development Goals (December 2000) (MDGs) directly relate to the right to health: reducing child mortality (4); improving maternal health (5) and combating HIV/AIDS, malaria and other diseases. 
have ratified the ICESCR. Without purporting to offer a definitive answer to this question, it is arguable that all states are legally bound by the human right to health by means of one or both of the following routes: (a) on the basis that most of the provisions of the UDHR (which, in itself is formally merely a declaration, hence not legally binding), and potentially also the ICESCR, have acquired the status of universal customary international law; 5 and (b) on the basis that all states (except South Sudan) have ratified one or more treaties that include at the very least key elements of the right. ${ }^{6}$ These other treaties include the International Convention on the Elimination of all Forms of Racial Discrimination (ICERD), ${ }^{7}$ the Convention on the Elimination of all Forms of Discrimination against Women (1979) (CEDAW), ${ }^{8}$ the Convention on the Rights of the Child, (1989), ${ }^{9}$ and numerous others besides. ${ }^{10}$

As previously discussed in the Framework Report, the idea of minimum core obligations does not explicitly figure in the binding treaties mentioned above. Instead, the primary international sources for the doctrine of minimum core obligations are the General Comments issued by various treaty bodies, above all the ESCR Committee (henceforth, 'the Committee'). These General Comments do not, in their own right, possess binding legal force. Nonetheless, insofar as the minimum core doctrine $(\mathrm{MCD})$ represents a correct interpretation of the relevant treaty, it is to that extent binding. It is strongly arguable that the MCD is a sound interpretation of the relevant treaty law on economic, social and cultural rights, if understood in the way recommended in the Framework Report: as a sub-set of obligations associated with economic, social and cultural rights that set a limit to the doctrine of progressive realization because they are to be immediately complied with in full by all states

The doctrine of progressive realization is set out in Article 2 of the ICESCR. It obligates states parties to 'take steps, individually and through international assistance and co-operation, especially economic and technical, to the maximum of its available resources, with a view to achieving progressively the full realization of the rights recognized in the present Covenant by all appropriate means, including particularly the adoption of legislative measures'. Progressive realization confers a general permission on states to phase in full compliance with ICESCR rights to the extent that resource constraints ('maximum available resources') make this necessary. The MCD, however, sets a limit to this permission by specifying a sub-set of obligations associated with ICESCR rights that must be complied with immediately and in full by all states. The MCD establishes a universal floor of immediate compliance, but not a ceiling, since states that are not hampered by resource constraints cannot avail themselves of the doctrine of progressive realization in order to avoid immediate compliance with those obligations to which the latter doctrine in principle applies.

This interpretation allows that some or all minimum core obligations may be justiciable, non-derogable or bear some special connection to an underlying value, such as human dignity or basic needs, but it does not treat these additional features as inherent in the very idea of a minimum core obligation. The rationale of the MCD, on this construal, is that it addresses a persistent problem regarding the temporal sequencing of human rights obligations in situations in which they cannot all be immediately complied with due to resource constraints. It picks out that sub-set of obligations that must be complied with immediately, as opposed to those obligations that may in principle be progressively realised over time due to resource shortages. This makes the MCD an essential tool in the fulfilment of human rights, given a world of pervasive resource constraints, thus facilitating the object and purpose

5 E Riedel, 'The Human Right to Health: Conceptual Foundations', in A. Clapham and M. Robinson (eds), Realizing the Right to Health (Rueffer \& Rub, 2009), 21, 22.

6 P. Hunt, 'Interpreting the International Right to Health in a Human Rights-Based Approach to Health', Health and Human Rights Journal (2016), p.13.

7 Article 5(e) (iv): 'States Parties undertake.. to guarantee the right to everyone... to public health, medical care, social security and social services'. International Convention on the Elimination of All Forms of Racial Discrimination, 21 December 1965, UNTS vol. 660, 195

8 Article 12(1)-(2) proscribes discrimination against women in the field of health care and requires States parties to ensure to women 'appropriate services in connection with pregnancy, confinement and the post-natal period, granting free services where necessary, as well as adequate nutrition during pregnancy and lactation'. Art 14(2) (b) concerns elimination of discrimination against women in rural areas, imposing an obligation to ensure 'access to adequate health care facilities, including information, counselling and services in family planning'.

9 Art 24(1): 'States parties recognise the right of the child to the enjoyment of the highest attainable standard of health and to facilities for the treatment of illness and rehabilitation of health. State Parties shall strive to ensure that no child is deprived of his or her access to such health care services.' More specific obligations re combating disease and malnutrition Art 24(2) (c) . CRC Committee Gen Comment 15 'The right of the child to the enjoyment of highest attainable standard of health' (17 April 2013) CRC/C/GC/15 elaborates on states' obligations re the right to health of children under Art 24, describing it as: 'extending not only to timely and appropriate prevention, health promotion, curative, rehabilitative and palliative services, but also a right to grow and develop to their full potential, and live in conditions that enable them to attain the highest standard of health by implementing programmes that address the underlying determinants of health'.

10 E.g. Arts 28, 43(e) and 45 of the International Convention on the Protection of the Rights of all Migrant Workers and Members of their Families (1990) and Art 25 of the Convention on the Rights of Persons with Disabilities (2006) 
of the ICESCR, as well as other human rights treaties in which the doctrine of progressive realization figures.

The Committee's General Comment 3 introduces the concept of 'minimum core obligations' in referring to 'a minimum core obligation to ensure the satisfaction of, at the very least, minimum essential levels of each of the rights' enumerated in the ICESCR. In relation to the right to health, the relevant obligations are said to include 'essential primary health care. ${ }^{11}$ Evidently, the Comment does not purport to offer an exhaustive specification of minimum core obligations, hence it should be interpreted as affirming that provision of 'essential primary health care' forms a part, but not necessarily the whole, of the minimum core obligations associated with the human right to health. This leaves open the possibility that forms of secondary and tertiary health care, or certain social determinants of health, also figure among the right's minimum core obligations. Nevertheless, General Comment 3 was arguably justified in positing a special connection between primary health care and minimum core obligations, since there is a 'synergy' between 'the first and basic measure in the design of any effective health care system [primary health care]' and the notion of obligations of immediate effect not subject to progressive realization [minimum core obligations]..$^{12}$

This still leaves us with two questions: (a) what is 'primary health care'?, and (b) what counts as 'essential' primary health care, on the assumption that 'essential' picks out obligations of immediate effect not subject to progressive realization. Regarding the first question, we can take as a general point of departure the elaboration of 'primary health care' in Article VII of the Declaration of Alma-Ata International Conference on Primary Health Care, Alma-Ata, USSR, 6-12 September 1978:

Primary health care:

1. reflects and evolves from the economic conditions and sociocultural and political characteristics of the country and its communities and is based on the application of the relevant results of social, biomedical and health services research and public health experience;

2. addresses the main health problems in the community, providing promotive, preventive, curative and rehabilitative services accordingly;

3. includes at least: education concerning prevailing health problems and the methods of preventing and controlling them; promotion of food supply and proper nutrition; an adequate supply of safe water and basic sanitation; maternal and child health care, including family planning; immunization against the major infectious diseases; prevention and control of locally endemic diseases; appropriate treatment of common diseases and injuries; and provision of essential drugs;

4. involves, in addition to the health sector, all related sectors and aspects of national and community development, in particular agriculture, animal husbandry, food, industry, education, housing, public works, communications and other sectors; and demands the coordinated efforts of all those sectors;

5. requires and promotes maximum community and individual self-reliance and participation in the planning, organization, operation and control of primary health care, making fullest use of local, national and other available resources; and to this end develops through appropriate education the ability of communities to participate;

6. should be sustained by integrated, functional and mutually supportive referral systems, leading to the progressive improvement of comprehensive health care for all, and giving priority to those most in need;

7. relies, at local and referral levels, on health workers, including physicians, nurses, midwives, auxiliaries and community workers as applicable, as well as traditional practitioners as needed, suitably trained socially and technically to work as a health team and to respond to the expressed health needs of the community.

This is an extremely wide-ranging characterization, going beyond the provision of medical services by health professionals. And, as many have pointed out, it can be interpreted as an enormously demanding set of requirements. Whatever its merits as a characterization of "primary health care", it seems too maximalist to serve as a feasible answer to our second question: what is "essential primary health care" for the purposes of defining minimum core obligations? Pursuing this line of thought, John Tobin has advocated as a starting-point a 'selective primary health care model' suggested by UNICEF, which became known as the GOBI $\mathrm{FF}^{13}$ This encompasses 'growth monitoring for under nutrition, oral rehydration therapy to treat childhood diarrhoea, breastfeeding to ensure the health of young children and immunization against six deadly childhood diseases' supplemented by 'food supplementation, family spacing and female education'. ${ }^{14}$ Tobin goes on to combine this 'selective primary health care' with the provision of food and water

\footnotetext{
11 Para. 10.

12 J. Tobin, The Right to Health in International Law (Oxford: Oxford University Press, 2012), p.250.

13 J. Tobin, The Right to Health in International Law, pp.250-1.

14 UNICEF, State of the World's Children 2009 (New York, 2009), p.31.
} 
necessary for survival as an account of a feasible set of minimum core obligations associated with the right to health. ${ }^{15}$ Although this suggestion has considerable merit at the level of principle, three observations are worth making about it. First, that it is arguable that it also ranges too broadly in virtue of including within the scope of the right to health elements that properly belong to other rights, such as the rights to water and adequate food. This classificatory issue turns on whether we adopt an 'inclusive' account of the right to health that includes within its compass large numbers of other rights. Second, the formulation offered still seems problematically vague, as it specifies certain forms of provision without offering sufficiently determinate guidance as to the crucial question of the level of provision that constitutes the minimum core of the relevant obligation. What level of monitoring for under nutrition, for example, satisfies the minimum core obligation? What is the amount of food or water 'necessary for survival'? Third, despite its strength at the level of principle, it does not enjoy strong support in international legal practice as an exhaustive account of the minimum core obligations of the right to health. This becomes obvious when we turn to perhaps the most prominent explication of those obligations, which is to be found in the ESCR Committee's General Comment 14.

General Comment 14 (2000) adopts a very wide-ranging characterization of the human right to health as a whole. In addition to health care narrowly conceived largely as services delivered by medical professionals, the Committee interprets the right expansively in at least two important ways. First, it adopts a radically 'inclusive' interpretation of the right to health with respect to other human rights, which it treats as 'integral components' of the former:

The right to health is closely related to and dependent upon the realisation of other human rights, as contained in the International Bill of Rights, including the rights to food, housing, work, education, human dignity, life, non-discrimination, equality, the prohibition against torture, privacy, access to information, and the freedoms of association, assembly and movement. These and other rights and freedoms address integral components of the right to health. ${ }^{16}$

Second, it includes extensive public health measures and social determinants of health within the content of the right to health.

The Comment also address the unwillingness or inability of a state to abide by the obligations under the right to health as follows: 'A State which is unwilling to use the maximum of its available resources for the realisation of the right to health is in violation of its obligations... If resource constraints render it impossible for a State to comply fully with its Covenant obligations, it has the burden of justifying that every effort has nevertheless been made to use all available resources at its disposal in order to satisfy, as a matter of priority, the obligations outlined above'. ${ }^{17}$ States unable to comply with right to health are under an obligation to seek international cooperation and assistance, ${ }^{18}$ while developed countries have an obligation to provide cooperation \& assistance (Art 2(1) ICESCR).

The Comment sets out schedule of minimum core obligations under the right to health in para 43 (a)-(f):

(a) To ensure the right of access to health facilities, goods and services on a non-discriminatory basis especially for vulnerable or marginalized groups;

(b) To ensure access to the minimum essential food which is nutritionally adequate and safe, to ensure freedom from hunger to everyone;

(c) To ensure access to basic shelter, housing and sanitation and an adequate supply of safe and potable water;

(d) To provide essential drugs from time to time defined under the WHO Action Programme on Essential Drugs;

(e) To ensure equitable distribution of all health facilities, goods and services;

(f) To adopt and implement a national public health strategy and plan of action on the basis of epidemiological evidence, addressing the health concerns of the whole population; the strategy and plan of action shall be devised and periodically reviewed, on the basis of a participatory and transparent process; they shall include methods, such as right to health indicators and benchmarks, by which progress can be closely monitored; the process by which the strategy and plan are devised as well as

15 J. Tobin, The Right to Health in International Law, p.247.

16 General Comment 14, the right to health, para 3.

17 General Comment 14, the right to health, para 5.

18 General Comment 14, the right to health, para 52. 
their content, shall give particular attention to all vulnerable and marginalized groups

In a shift of terminology left unexplained, the Comment then lists a series of obligations of "comparable priority" to those enumerated as featuring in the minimum core: ${ }^{19}$

(a) To ensure reproductive, maternal (pre-natal as well as post-natal) and child health care;

(b) To provide immunization against the major infectious diseases occurring in the community;

(c) To take measures to prevent, treat and control epidemic and endemic diseases;

(d) To provide education and access to information concerning the main health problems in the community, including methods of preventing and controlling them; and

(e) To provide appropriate training for health personnel, including education on health and human rights.

The Committee described these minimum core obligations as non-derogable: 'a State party cannot, under any circumstances whatsoever, justify its non-compliance with the core obligations, set out above... which are non-derogable'. ${ }^{20}$ This contrasts with General Comment no.3, which appears to envision that minimum core obligations may be overridden in some cases of resource constraints: 'in order for a State part to be able to attribute its failure to meet at least its minimum core obligations to a lack of available resources it must demonstrate that every effort has been made to use all resources at are at its disposition in an effort to satisfy, as a matter of priority, those minimum obligations'. The non-derogability of the minimum core obligations of the right to health was apparently reaffirmed more recently in a report of the Special Rapporteur on the right to health. ${ }^{21}$ However, given that, as the General Report recounts, there is compelling reason to dissociate the notion of minimum core obligations from that of non-derogability, and that Special Rapporteurs on other human rights acknowledge the possibility of derogation, the question arises why, in relation to the right to health, the relevant minimum core obligations should be interpreted as non-derogable. This is not ruled out conceptually, but it would appear to be a very difficult conclusion to establish, especially given the onerousness of the obligations that have been so specified.
Clearly, General Comment 14 offers a more detailed and expansive set of minimum core obligations than General Comment 3's terse reference to "essential primary health care". Perhaps its most compelling contribution is the emphasis it places on non-discrimination in the access to health facilities, services and goods in para 43(a). This non-discriminatory norm seems a pre-eminent candidate for inclusion within the minimum core of the right to health because it reflects a background right of non-discrimination (Art. 2(2) of the Covenant) which, like civil and political rights generally, imposes obligations of 'immediate effect'.22 Another significant aspect of the account of minimum core obligations elaborated by the comment is the emphasis on transparent and participatory procedures in the formulation of health policy in para 43(f). Both innovations highlight the fact that in addition to the delivery of goods and services, minimum core obligations of the right to health may also incorporate demands regarding just procedures.

Nonetheless, General Comment 14 remains vulnerable to the objection that the items on its list of minimum core obligations, and those of comparable priority, are highly indeterminate, both as to the kind of benefits involved and the cost or level at which these benefits must be provided in order to comply with the relevant obligation. So, to take para 44(c), which kinds of measures to 'prevent, treat and control epidemic and endemic diseases' must be adopted, and at what level of cost, in order to comply with the minimum core obligation? And how is the 'equitable distribution' required under para. 43(e) to be understood-as strict equality or something less demanding? Again, what counts as an 'adequate supply' of safe and potable water? Of course, the questions are all-too-easily multiplied. It would seem that the drafters of the Comment were more intent on specifying an ambitious set of minimum core obligations, in rather broad-brush terms, than on laying down very precise guidance regarding their content. This is not necessarily a devastating criticism of the General Comment, but it does

\footnotetext{
19 General Comment 14, the right to health, para 44.

20 General Comment 14, the right to health, para 47.

${ }^{21}$ Right of Everyone to the enjoyment of the highest attainable standard of health", (11 August 2014) UN Doc A/69/150, para 11: 'Even if an obligation of immediate effect depends on resources, a State may not rely on the lack of resources as a defence or excuse for not fulfilling the obligation'.

22 See also CEDAW COMMITTEE, Gen Rec 24 on the right to health of women under article 12 of the Convention. Committee on the Elimination of Discrimination against Women, General Recommendation No. 24, 'Women and Health', UN Doc A/54/38 Rev 1 (1999): states under an obligation to ensure non-discriminatory access to health care for women, and that these health care services must take into account the particular needs of women.
} 
suggest that considerably more interpretative work needs to be done to render its specification of minimum core obligations an effective practical guide for states parties to the ICESCR.

The Committee's characterization of the minimum core obligations in General Comment 14 is subject to additional criticisms, over and above the familiar concerns about the indeterminacy of its components just rehearsed. The first objection is that there is a lack of clarity as to the relationship between those obligations that are explicitly identified as 'core' obligations and those designated as enjoying 'comparable priority'. It is unclear whether the latter are also strictly core obligations. Or, if they are not, whether, unlike the former, they are subject to the doctrine of progressive realization in cases of resource scarcity. ${ }^{23}$ The reference to 'comparable priority' does not explain which dimensions of 'priority'immediacy, justiciability, non-derogability, etc-are operative in the comparison. Second, there is a problem regarding the scope of the obligations specified as constituting the minimum core. These apparently include obligations pertaining to subject matters, such as provision of food and housing, that arguably do not strictly fall within the parameters of the right to health, but rather correspond to other rights in the Covenant articles, such as the rights to adequate food and housing. The third, and perhaps most damaging, objection concerns the content of the obligations enumerated by the Committee as minimum core or of 'comparable priority'. These seem overly demanding to be feasibly conceived as obligations of immediate effect incumbent on all states, especially on an invariant reading of the MCD.

One version of the third objection is articulated by John Tobin in his comprehensive monograph, The Right to Health in International Law:

[F]rom a purely practical perspective, for many states the capacity to ensure the realization of these minimum core obligations will remain as distant as the prospect of the full realization of the right to health itself. To take just one example, the requirement to not only adopt buy implement a national health strategy based on epidemiological evidence attendant with relevant benchmarks, indicators, and monitoring and review mechanisms is an objective that many developed states would struggle to achieve... As a consequence the vision of the minimum core obligations of states under the right to health, as advanced by the ESC Committee, is dissociated from the capacity of states to realize this vision. It simply does not offer a principled, practical, or coherent rationale with is sufficiently sensitive to the context in which the right to health must be operationalized. (p.240). ${ }^{24}$

Another, somewhat more sophisticated version of the third objection has recently been advanced by Lisa Forman and her co-authors. They focus on the inter-dependence between the international duty of assistance and cooperation, highlighted in paragraph 45 of General Comment 14, and the content of the minimum core obligations whose non-fulfilment activates the former. According to the authors, the General Comment's vagueness as to the content of both of these obligations threatens to result in poorer states, in particular, being saddled with unrealistically onerous minimum core obligations:

[T] he committee fails to develop a process or specify criteria for assessing when a state has expended its maximum available resources, thus triggering the obligations of international assistance and cooperation specified in paragraph 45 . The committee also fails to suggest a burden-sharing mechanism for managing this shared responsibility to realize the core obligations. This failure to clarify the international assistance obligations of wealthy states while specifying that poorer countries hold strong duties to meet core obligations irrespective of resources leaves the core open to the charge that it places financially unrealistic obligations on poorer countries. ${ }^{25}$

Notwithstanding the compelling critique that can be mounted of the excessively wide-ranging and demanding list of minimum core obligations (or equivalents) countenanced by General Comment 14, it appears that something very much

${ }^{23}$ L. Forman, C. Beiersmann, C.E. Brolan, M. McKee, R. Hammonds and G. Ooms, 'What Do Core Obligations Under the Right to Health Bring to Universal Health Coverage?', Health and Human Rights Journal 18 (2016), p.7.

24 J.Tobin, The Right to Health in International Law, p.240. For a similar view: 'The reality is that most low-income countries are too poor to fulfil the core obligations or even provide a basic package of health services for all, which the WHO estimates would cost US $\$ 40$ per person per year': O. Oluduro and E. Durojaye, 'The Normative Framework on the Right to Health under International Human Rights Law', in E. Durojaye (ed), Litigating the Right to Health in Africa: Challenges and Prospects (London: Routledge, 2016), p.35. 25 L. Forman, C. Beiersmann, C.E. Brolan, M. McKee, R. Hammonds and G. Ooms, 'What Do Core Obligations Under the Right to Health Bring to Universal Health Coverage?', Health and Human Rights Journal 18 (2016), p.5. 
like this list is reaffirmed by the Special Rapporteur on the right to health's recent report:

Certain health obligations are of immediate effect and are not subject to progressive realization. This includes core obligations, such as non-discrimination. The Sustainable Development Goals reflect a number of core obligations, such as access to health facilities, goods and services on a non-discriminatory basis, access to food, shelter, housing and sanitation, safe and potable water and essential medicines, and ensuring universal coverage of health-care services. Other core obligations that will be essential to realizing the Goals include the revision of the national and subnational legal and policy environment and the amendment or enactments of laws and policies when necessary; the adoption of a national health strategy that addresses the right to health; and the equitable distribution of health facilities, goods and services. ${ }^{26}$

In a similar expansive vein, the ESCR's Committee's General Comment No.22, on The Right to Sexual and Reproductive Health, specifies core obligations in this sub-field of the human right to health as follows (para 49):

49. States parties have a core obligation to ensure the satisfaction of, at the very least, minimum essential levels of the right to sexual and reproductive health. In this regard, States parties should be guided by contemporary human rights instruments and jurisprudence, as well as the most current international guidelines and protocols established by the UN agencies, in particular WHO and UNFPA. The core obligations include at least the following:

(a) To repeal or eliminate laws, policies and practices that criminalize, obstruct or undermine individual's or particular group's access to sexual and reproductive health facilities, services, goods and information;

(b) To adopt and implement a national strategy and action plan, with adequate budget allocation, on sexual and reproductive health, which is devised, periodically reviewed and monitored through a participatory and transparent process, disaggregated by the prohibited grounds of discrimination; (c) To guarantee universal and equitable access to affordable, acceptable and quality sexual and reproductive health services, goods and facilities, in particular for women and disadvantaged and marginalized groups;

(d) To enact and enforce the legal prohibition of harmful practices and gender-based violence, including female genital mutilation, child and forced marriages and domestic and sexual violence including marital rape, while ensuring privacy, confidentiality and free, informed and responsible decision-making, without coercion, discrimination or fear of violence, on individual's sexual and reproductive needs and behaviours;

(e) To take measures to prevent unsafe abortions and to provide post-abortion care and counselling for those in need;

(f) To ensure all individuals and groups have access to comprehensive education and information on sexual and reproductive health, that is non-discriminatory, non-biased, evidence-based and taking into account the evolving capacities of children and adolescents;

(g) To provide medicines, equipment and technologies essential to sexual and reproductive health, including based on the WHO Essential Medicines List; and

(h) To ensure access to effective and transparent remedies and redress, including administrative and judicial ones, for violations of the right to sexual and reproductive health.

\section{Conclusion}

In conclusion, although the MCD in relation to the human right to health has established a firm foothold within international law and practice, serious concerns persist about both the determinacy and the feasibility of the content of minimum core obligations as articulated by General Comment 14. Of course, this tendency to indeterminacy and over-reach is not

26 "Right of everyone to the enjoyment of the highest attainable standard of physical and mental health" (5 August 2016), UN Doc A/71/304, para. 28. See also para 77 . 
a phenomenon confined to the articulation of minimum core obligations; rather, as many critics have argued, it is exhibited by human rights discourse more generally, and perhaps especially in relation to the domain of economic, social and cultural rights. Against this, however, we should recognize that the international legal order is still at a comparatively early stage in articulating the content of the human right to health, including the minimum core obligations associated with it. As Paul Hunt, former UN Special Rapporteur on the right to health, and lead author of General Comment 14, has observed recently: 'Guidelines on international economic, social, and cultural rights are increasing. Nonetheless, on the whole, the international interpretation and application of these human rights is a relatively recent enterprise'.27 Although, to this extent, the minimum core obligations of the right to health remain a work in progress, I believe the foregoing analysis gives ample grounds for highlighting at least the following dimensions of such obligations, with the caveat that the fourth dimension may be better placed within the compass of other rights than the human right to health:

- Selective essential primary health care

- Non-discrimination in health care provision

- Participation and transparency in the formation of health policy

- Provision of minimum levels of food and water

27 P. Hunt, 'Interpreting the International Right to Health in a Human Rights-Based Approach to Health', Health and Human Rights Journal (2016), p.13. 


\section{Regional Law and Practice}

\section{Africa}

The central regional human rights instrument in the African context is The African Charter on Human and Peoples' Rights (the Banjul Charter), which has been ratified by 53 African states, and provides a framework for human rights protection in the continent..$^{28}$ Allegations of human rights violations can be heard by the African Court on Human and Peoples' Rights, the African Commission on Human and Peoples' Rights, and the African Committee on the Rights and Welfare of the Child. The Charter authorizes these treaty bodies to draw on principles of international human rights law in assessing the compliance of states with the treaty (Art. 60). Article 16 of the Charter sets out a right to health:

1. Every individual shall have the right to enjoy the best attainable state of physical and mental health.

2. States parties to the present Charter shall take the necessary measures to protect the health of their people and to ensure that they receive medical attention when they are sick.

The African Commission on Human and Peoples' Rights, which oversees and interprets the charter, has formulated Principles and Guidelines on the Implementation of Economic, Social, and Cultural Rights in the Banjul Charter in which it explicitly adopts the concept of 'minimum core obligations. ${ }^{29}$ In line with the analysis adopted in the Framework Report, the Principles characterize 'minimum core obligations' as among 'immediate' obligations that set a limit to the doctrine of progressive realization (para. 16):

Despite the obligation to progressively realise economic, social and cultural rights, some of the obligations imposed on States parties to the African
Charter are immediate upon ratification of the Charter. These obligations include but are not limited to the obligation to take steps, the prohibition of retrogressive steps, minimum core obligations and the obligation to prevent discrimination in the enjoyment of economic, social and cultural rights.

The Principles treat minimum core obligations as obtaining regardless of the availability of resources and as nonderogable. One significant implication of the MCD, drawn by the Principles, is that in the case of 'demonstrable resource constraints' a state 'should prioritise the realisation of the rights for the poorest and most vulnerable in society' (para. 17). Turning specifically to the right to health, the Principles identify the following minimum core obligations associated with that right, echoing much of the analysis in General Comment 14 (para 67):

The minimum core obligations of the right to health include at least the following:

a. Ensure the right of access to health facilities, goods and services on a non-discriminatory basis, especially for vulnerable or marginalised groups;

28 OAU Doc CAB/LEG/67/3/Rev 5, adopted 27 June 1981, entered into force 21 Oct 1986. African Commission on Human and Peoples' Rights in Social and Economics Rights Action Center (SERAC) and Another v Nigeria (2001) AHRLR 60 (ACHPR) on art 16 of the Charter - direct and justiciable obligations on states, not limited to health care. See also, S Kiapi, 'Interpreting the Right to Health under the African Charter', East African Journal of Peace and Human Rights 11 (2015): 1.

29 African Commission on Human and Peoples' Rights, Principles and Guidelines on the Implementation of Economic, Social and Cultural Rights in the African Charter on Human and Peoples' Rights, http://www.achpr.org/files/instruments/economic-social-cultural/ achpr_instr_guide_draft_esc_rights_eng.pdf 
b. Ensure the provision of essential drugs to all those who need them, as periodically defined under the WHO Action Programme on Essential Drugs, and particularly anti-retroviral drugs;

c. Ensure universal immunisation against major infectious diseases;

d. Take measures to prevent, treat and control epidemic and endemic diseases;

e. Provide education and access to information concerning the main health problems in the community, including methods of preventing and controlling them.

The concept of minimum core obligations, specially understood as obligations of immediate effect, is mobilised also in the Commission's 'Resolution on Access to Health and Needed Medicines in Africa', ${ }^{30}$ which requires states to meet 'immediately... the minimum core obligations of ensuring availability and affordability to all of essential medicines as defined by the country's essential medicines list and the WHO Action Programme on Essential Drugs'.

There has not been a significant amount of litigation on the right to health at either national or regional levels in Africa. ${ }^{31}$ However, one regional case worth mentioning is Purohit $v$ The Gambia, where the Commission not only accepted the doctrine of progressive realization-the doctrine that provides the background rationale for the MCD's operation-but also stressed the importance of non-discrimination in the fulfilment of the right to health, an element with a strong claim to inclusion within the core obligations associated with that right: 'having due regard to this depressing but real state of affairs [poverty in Africa rendering the full realization of the right to health impossible), the African Commission would like to read into article 16 the obligation on part of states party to the African Charter to take concrete and targeted steps, while taking full advantage of its available resources, to ensure that the right to health is fully realised in all its aspects without discrimination of any kind., ${ }^{32}$

\section{Inter-American System}

The Inter-American system of human rights comprises the Inter-American Commission on Human Rights and the Inter-American Court of Human Rights. The former issues both general thematic and country reports and assesses petitions alleging human right violations. In the event of non-compliance with its recommendations the Commission is empowered to submit the case to the Court for adjudication..$^{33}$ In a 2013 report the Inter-American Commission on Human Rights appeared to acknowledged the existence of obligations of 'immediate effect' - essentially, equivalent to "minimum core" obligations-that constrain the application of the doctrine of progressive realization:

While the American Convention and the Protocol of San Salvador recognize the progressive development of economic, social and cultural rights, under Article 1 of the Protocol of San Salvador States parties undertake to immediately adopt the necessary measures, to the extent allowed by their available resources and taking into account their degree of development, for the purpose of achieving the full observance of the rights recognized in the Protocol. This obligation of immediate effect is recognized in Article 2 of the ICESCR. The inference of the foregoing is that States are prohibited from adopting regressive measures in the area of economic, social and cultural rights. ${ }^{34}$

This passage is not, however, a very perspicuous statement of the minimum core doctrine, nor is the inference from that doctrine to the prohibition of regressive measures. However, further support for the presence of the MCD in the Inter-American context can be derived from the Commission's assertion that, despite the application of the doctrine of progressive realization, member States bore an obligation 'regardless of the level of economic development, to guarantee a minimum threshold of these rights [in the American Declaration and the American Convention], ${ }^{35}$

In Acevedo $v$ Peru, ${ }^{36}$ the Court extensively quoted a statement of the ESCR Committee that explicitly identified minimum core obligations as among the relevant objective criteria in applying the doctrines of progressive realization and non-retrogression:

30 The African Commission on Human and Peoples' Rights, meeting at its 44th Ordinary Session held in Abuja, Federal Republic of Nigeria, from the 10th to 24th November 2008, available http:// www.achpr.org/sessions/44th/resolutions/141/

31 See, for a comprehensive and recent overview, E. Durojaye (ed), Litigating the Right to Health in Africa: Challenges and Prospects.

32 Purohit $v$ The Gambia (2003) AHRLR 96, para 84.

33 For a useful overview of the protection of the right to health in the Inter-American system, see Oscar Parra-Vera, 'The Protection of the Right to Health through Individual Petitions before the Inter-American System of Human Rights', in E. Durojaye, Litigating the Right to Health in Africa: Challenges and Prospects.

34 Inter-American Commission on Human Rights, 'Human Rights of Migrants and Other Persons in the Context of Human Mobility in Mexico' (2013), available at https://www.oas.org/en/iachr/migrants/ docs/pdf/Report-Migrants-Mexico-2013.pdf. (At paras. 585-86).

35 Annual Report of the Inter-American Commission on Human Rights 1993, OEA/Ser.L/V.85, Doc. 9 rev.11 February 1994, Chapter V, available at http://www.cidh.org/annualrep/93eng/chap.5.htm 
In accordance with the Committee on Economic, Social and Cultural Rights, '[s]hould a State party use "resource constraints" as an explanation for any retrogressive steps taken,... would consider such information on a country-by-country basis in the light of objective criteria such as:... b) the severity of the alleged breach, in particular whether the situation concerned the enjoyment of the minimum core content of the Covenant..

A year later, the minimum core obligation "to ensure access to ... an adequate supply of safe and potable water", specified by the ESCR Committee as part of the right to health (General Comment No. 14, para. 43(c)), was recognized by the Court in Xákmok Kásek Indigenous Community v. Paraguay. ${ }^{37}$ The Court found that Paraguay, by failing to provide sufficient amounts of water to an indigenous community that had been forced off its land, violated the right to a dignified life under Article 4(1) of the American Convention. The Court cited General Comment No. 15 of the CESCR in support of a specific minimum obligation to provide 7.5 liters of water per person per day:

The Court observes that the water supplied by the State from May to August 2009 amounted to no more than 2.17 liters per person per day. In this regard, according to international standards, most people need a minimum of 7.5 liters per day per person to meet all their basic needs, including food and hygiene. . . . Judged by these standards, the State has not proved that it is supplying sufficient amounts of water to meet the minimum requirements. ${ }^{38}$

The Court directly addressed the right to health in Gonzales Lluy and Family $v$ Ecuador, ${ }^{39}$ a case involving treatment for infection with HIV as a result of a blood transfusion. In a key passage, the Court explicitly drew a connection between the right to health in the Protocol of San Salvador and the minimum core obligations set out in General Comment 14, especially to provide essential drugs:

In this regard, the Court notes that the Protocol of San Salvador establishes that, among the measures to ensure the right to health, States must promote "universal immunization against the principal infectious diseases"; "prevention and treatment of endemic, occupational and other diseases," and "satisfaction of the health needs of the highest risk groups and of those whose poverty makes them the most vulnerable." Similar obligations are established in Article 12(2) of the International Covenant on Economic, Social and Cultural Rights. This framework of obligations includes different duties that relate to access to medication. According to General Comment No. 14, the right to the highest attainable standard of health gives rise to some minimum core obligations that include: "[t]o provide essential drugs, as from time to time defined under the WHO Action Programme on Essential Drugs. ${ }^{40}$

The Court protected the right to health through its connectivity with the justiciable rights to life and to personal integrity, finding a violation of 'the obligation to monitor and supervise the provision of health care services, within the framework of the right to personal integrity and of the obligation not to endanger life.. ${ }^{41}$

\section{Europe}

The Council of Europe's 1950 Convention for the Protection of Human Rights and Fundamental Freedoms (ECHR) is a statement of civil and political rights and, as such, does not feature a right to health. ${ }^{42}$ Nonetheless, it is arguable that the European Court of Human Rights has over the years interpreted various of its articles in such a way as to protect aspects of the right to health. The Revised European Social Charter, however, includes in its Article 11 a right to health

${ }_{36}$ Acevedo Buendia et al ('Discharged and Retired Employees of the Office of the Comptroller') v Peru, Preliminary Objection, Merits, Reparations and Costs, Judgment of 1 July 2009, I/A Court HR Series C No. 198, para 10 (italics added)

37 Xákmok Kásek Indigenous Community v. Paraguay, Series C no. 21 (2010) http://www.corteidh.or.cr/docs/casos/articulos/ seriec_298_ing.pdf. See also subsequent case of Chinchilla Sandoval and Others $v$ Guatemala http://www.corteidh.or.cr/docs/casos/ articulos/seriec_312_esp.pdf (regarding a woman with diabetes who died in prison, raising questions of access to adequate treatmentcase not yet available in English translation).

38 Xákmok Kásek Indigenous Community v. Paraguay, para. 195, footnotes omitted.

39 Gonzales Lluy and Family v Ecuador (Judgment of 1 September, 2015).

40 Id., para. 193.

41 Id., para. 193. 
but makes no explicit reference to "minimum core obligations" or obligations of immediate effect, although it does employ the locution 'take appropriate measures', which is suggestive of the doctrine of progressive realization:

With a view to ensuring the effective exercise of the right to protection of health, the Parties undertake, either directly or in cooperation with public or private organisations, to take appropriate measures designed inter alia:

1. to remove as far as possible the causes of ill-health;

2. to provide advisory and educational facilities for the promotion of health and the encouragement of individual responsibility in matters of health;

3. to prevent as far as possible epidemic, endemic and other diseases, as well as accidents.

Moreover, although the European Committee of Social Rights, which is charged with monitoring compliance with the Social Charter, seems to have countenanced the notion of progressive realization of social rights, which in turn provides a foothold for the MCD. ${ }^{43}$

\section{Conclusion}

The inevitably selective discussion in this section yields a rather complex picture. As in the international context, the MCD is not explicitly present in regional treaties, but has in some regions - primarily Africa and the Americas - emerged as an important tool in interpreting treaty provisions, effectively setting a limit to the operation of the doctrine of progressive realization by identifying obligations of immediate effect. Moreover, among those regional regimes that employ the MCD, there is some convergence to key elements of the General Comment 14 list, especially with respect to essential drugs, the provision of water and food, and non-discrimination. It is obvious, however, that the MCD is not universally endorsed in relation to economic, social and cultural rights and, where it is endorsed, it is often interpreted differently so as to yield divergent specific obligations. However, in assessing both of these factors, it is important to bear in mind the following facts: (a) regional human rights regimes vary in the extent to which they have developed a sophisticated jurisprudence on economic, social and cultural rights
- including the recognition of an independent human right to health - and that emphasis may be given to those regions that have made greater progress, (b) the notion of minimum core obligations may be of greatest salience in those regions, such as Africa, that face the gravest resource constraints in meeting human rights obligations, whereas regions facing less challenging circumstances have correspondingly lesser need to elaborate an MCD, (c) divergence as to the content of minimum core obligations may to some degree reflect the use of two different versions of the MCD - the invariant version, which specifies a uniform set of minimum core obligations applicable to all states, and the variable version, according to which the sub-set of minimum core obligations will differ from one state to another in accordance with resources variations among them; and (d) the appearance of diversity as to the content of minimum core obligations may to some degree be mitigated once we recognize that articulations of a list of minimum core obligations do not usually purport to be exhaustive. Nonetheless, insofar as the list of minimum core obligations outlined in General Comment 14 continues to exert an influence on regional understandings of the MCD, those understandings inherit the defects we have already identified with that list.

42 Most prominent is Article 2, on the right to life, which has been used in matters concerning abortion (Hv. Norway (1992) 73 DR 155, resource allocation within health care systems (Osman v. UK (1998) 29 EHRR 245; Scialaqua $v$. Italy (1998) 26 EHRR 164), the 'right to die' (Pretty v. UK (2002) 35 EHRR 1), and also more recently regarding equality of access to health care of adequate quality ( Cyprus vTurkey (2001) Bo,25781/94, Senturk and Senturk v. Turkey (2013) No.13423/09, Asiye Genc v Turkey (2015) No.24109/07 and Aydogu $v$ Turke (2016) ECHR 719y. Regarding the latter, see L. Graham, 'The European Court of Human Rights and the Emerging Right to Health', http://ohrh.law.ox.ac.uk/the-european-court-of-human-rights-andthe-emerging-right-to-health/ Other articles invoked in a right to health context include Article 5 on the right to liberty and security of the person, Article 8 on the right to privacy, and Article 12 on the right to marry and found a family.

43 Autism-Europe (IAAE) v. France (2003), http://www.right-to-education.org/sites/right-to-education.org/files/resource-attachments/ ESC_The_Right_to_Education_under_the_European_Social_Charter_2006_en.pdf ; see also European Roma Rights Center v. Bulgaria, ECSR, Complaint 48/2008 (holding that states are required 'to guarantee minimum income and social assistance for persons without adequate resources'). 


\section{State Law and Practice}

\section{State Reports}

Given constraints of space, this report does not seek to add to the insightful analysis provided by Angelina Fisher at pages 26-31 of her report on the minimum core of the right to education (some of which relates to components, such as entitlements to food, arguably encompassed within the human right to health). In state reports to treaty bodies, states seldom use the language of minimum core obligations, so at best one is left with the difficult matter of trying to identify obligations that they regard as being of 'immediate effect' and hence not subject to the doctrine of progressive realization. The same is also true of recommendations and concluding comments issued by the treaty bodies on these reports.

\section{State Law}

\section{South Africa}

The jurisprudence of the Constitutional Court of South Africa has a special significance in relation to the doctrine of minimum core obligations pertaining to the right to health. First of all, the South African Constitution famously contains a Bill of Rights that prominently features socio-economic rights, in addition to being one of the few constitutions to include a justiciable right to health care. According to section 27(1) 'Everyone has the right to have access to - (a) health care services, including reproductive health care', while section 28(1) (c) confers on every child the right to 'basic nutrition, shelter, basic health care services and social services'. Second, the Constitution incorporates essentially the doctrine of 'progressive realization' in relation to many of those rights, a doctrine interpreted by the Court as 'bearing the same meaning in the Constitution as in the document [ICESCR] from which it was so clearly derived' ${ }^{44}$ For example, according to section 27(2), the state is required to 'take reasonable legislative and other measures, within its available resources, to achieve the progressive realization of each of these rights [in section 27(1)]'. As with the doctrine at the international level, the idea of 'progressive realization' is understood as an acknowledgement by the drafters that the right to which it applies 'could not be realized immediately' ${ }^{45}$ Thirdly, the court has built up an impressive and widely influential body of jurisprudence on socio-economic rights. Finally, there have been some prominent cases in which the Court has engaged with the doctrine of minimum core obligations, a fact partly attributable to the severe resource constraints and special demands, such as the highest number of HIV-positive people in the world (more than $17 \%$ of the world's population), that the country faces in fulfilling socio-economic rights.

The conventional view of the South African constitutional jurisprudence is that the Court has, in the words of one recent analysis, 'preferred the reasonableness test [in regard to the fulfilment of socio-economic rights] to the "minimum core obligation" developed by the CESCR at the international level'. ${ }^{46}$ Other commentators speak more bluntly of the Court having 'rejected' the minimum core concept. ${ }^{47}$ If true, this analysis would deal a blow to the practical viability and uptake of the MCD. However, on closer inspection the

44 Government of the Republic of South Africa \& others $v$ Grootboom and others, (CCT11/00) [2000] ZACC 19; 2001 (1) SA 4612000 (11) BCLR 1169 (4 October 2000), para.36.

45 Id. Para 35

46 E.J. Broster, 'Litigating the Right to Health Care in South Africa', in E. Durojaye (ed), Litigating the Right to Health in Africa: Challenges and Prospects, p.116

47 E. Posner, The Twilight of Human Rights Law (Oxford: Oxford University Press, 2014), pp.87-8 
relevant decisions do not obviously amount to an outright rejection of the MCD, but more plausibly a denial of the power of litigants to enforce any such obligations judicially so as to be immediately furnished with whatever benefits those obligations confer upon them. This analysis depends on distinguishing between the existence of minimum core obligations as obligations of immediate effect bearing on the state from the question whether, and in what manner, they may be judicially enforceable by individual litigants. It therefore fits with the tenor of the Framework Report, in which the concept of minimum core obligations is not taken to entail any claim about their judicial enforceability. This leaves it as an independent matter of institutional implementation how to secure them effectively and legitimately within any given constitutional order, a question regarding which different answers may be in order in different jurisdictions.

The key decision is that of the Constitutional Court of South Africa in Minister for Health $v$ Treatment Action Campaign. ${ }^{48}$ Referring to the previous decision in Grootboom, the Court dealt with the respondents' argument based on minimum core obligations in the following way:

“(33) In Grootboom reliance was also placed on the provisions of the Covenant. Yacoob J held that in terms of our Constitution the question is

"whether the measures taken by the State to realize the right afforded by s 26 are reasonable". (Id. Para 33).

(34) Although Yacoob J indicated that evidence in a particular case may show that there is a minimum core of a particular service that should be taken into account in determining whether measures adopted by the state are reasonable, (Id) the socio-economic rights of the Constitution should not be construed as entitling everyone to demand that the minimum core be provided to them. The idea of a minimum core was thus treated as possibly being relevant to reasonableness under section 26(2), and not as a self-standing right conferred on everyone under section 26(1).

(35) A purposive reading of sections 26 and 27 does not lead to any other conclusion. It is impossible to give everyone access even to a "core" service immediately. All that is possible, and all that can be expected of the state, is that it act reasonably to provide access to the socio-economic rights identified in sections 26 and 27 on a progressive basis.
So, on the one hand, no self-standing right is conferred on each individual to demand that the minimum core be immediately provided to them by judicial order; on the other hand, the concept may be relevant in determining whether measures adopted by the state to realize socio-economic rights are reasonable. This is hardly an outright rejection of the concept of minimum core obligations, but rather a rejection of the idea that litigants may seek the immediate judicial enforcement of their minimum core entitlements through the courts. An analysis in terms of reasonableness is not 'preferred' to one in terms of minimum core obligations; on the contrary, minimum core obligations are taken to be potentially relevant in determining whether reasonable measures to comply with rights have been undertaken. The claim that minimum core obligations are relevant to the test of reasonableness is persuasive: such obligations must be fulfilled immediately rather than progressively, so it will not be reasonable for a state to postpone, without good cause, for later the fulfilment a minimum core obligations which it has the resources to fulfill immediately. Meanwhile, if minimum core obligations are defeasible in light of competing concerns, such as may arise in emergency situations, then there will be a further question as to whether the competing considerations may reasonably be taken to trump the minimum core obligations. Arguably, such emergencies encompass the chronic resource shortages arising in the context of South Africa's HIV/AIDS pandemic.

The Court's rejection of the immediate judicial enforceability of such obligations reflects wider considerations about the role of the courts within an overall constitutional structure alongside the executive and legislative branches. On the one hand, judicial bodies are not typically as well-equipped as legislatures or executives to specify the content of minimum core obligations or the best practical measures for securing them. On the other hand, even to the extent that courts can identify such obligations, resource scarcity may demand that compliance with those obligations is traded-off against compliance with other pressing demands, and judgments about such trade-offs are more properly within the remit of other branches of government that are more directly democratically accountable. Both of these lines of thought seem to be present in the Court's analysis in TAC (No.2):

(37) It should be borne in mind that in dealing with such matters the courts are not institutionally equipped to make the wide-ranging factual and

${ }_{48}$ Minister for Health $v$ Treatment Action Campaign (No.2) CCT 8/02 (2002); [2002] ZACC 15; 2002 (5) SA 721; 2002 (10) BCLR 1033. 49 Id. paras 33-5 
political enquiries necessary for determining what the minimum-core standards called for by the first and second amici should be, nor for deciding how public revenues should most effectively be spent. There are many pressing demands on the public purse. As was said in Soobramoney: ${ }^{50}$

"The State has to manage its limited resources in order to address all these claims. There will be times when this requires it to adopt a holistic approach to the larger needs of society rather than to focus on the specific needs of particular individuals within society” (para 31).

(38) Courts are ill-suited to adjudicate upon issues where court orders could have multiple social and economic consequences for the community. The Constitution contemplates rather a restrained and focused role for the courts, namely, to require the state to take measures to meet its constitutional obligations and to subject the reasonableness of those measures to evaluation. Such determinations of reasonableness may in fact have budgetary implications, but are not in themselves directed at rearranging budgets. In this way the judicial, legislative and executive functions achieve appropriate constitutional balance". ${ }^{51}$

In the end, the Court held that the government policy of restricting the use of nevirapine, an antiretroviral drug used to combat mother-to-child transmission of HIV, to research and training sites, unreasonably excluded individuals in the case of whom such treatment was medically indicated..$^{52}$ Although this decision necessitated a revision of government policy on access to nevirapine, the Court emphasized that it did not mean that 'everyone can immediately claim access to such treatment, although the ideal... is to achieve that goal. Every effort must, however, be made to do so as soon as reasonably possible, ${ }^{53}$ In reaching this decision the Court did not explicitly deploy the minimum core doctrine, and it unclear whether it implicitly did so. What is clear, however, is that instead of rejecting that doctrine, the Court left open its potential relevance in assessments of reasonableness, while closing down the suggestion that litigants had a self-standing right to have core obligations immediately fulfilled in their own case on the basis of considerations pertaining to the limits of the judicial role.

This analysis seems to be confirmed by the most recent relevant decision, Mazibuko and Others $v$ City of Johannesburg, ${ }^{54}$ which concerned the right to access to water sufficient for a dignified life. The applicants argued that the right in section 27(1)(b) was to 50 litres per person per day, but explicitly rejected the notion that this amount was the minimum core obligations associated with the right. However, O'Regan J. held that the argument nevertheless failed for the same sorts of reasons that an explicit minimum core argument failed in both Grootboom and TAC No $2 .{ }^{55}$ If there is no justiciable right to be immediately provided with the minimum core of a right, there is a fortiori no such right in relation to the entirety of the right's associated obligations. Hence, on O'Regan J's interpretation of section 27 (1) and (2), it 'does not confer a right to claim "sufficient water" from the state immediately'. Elaborating, he stated:

It was not expected, nor could it have been, that the state be able to furnish citizens immediately with all the basic necessities of life. Social and economic rights empower citizens to demand of the state that it acts reasonably and progressively to ensure that all enjoy the basic necessities of life. In so doing, the social and economic rights enable citizen to hold government to account for the manner in which it seeks to pursue the achievement of social and economic rights. ${ }^{56}$

On one interpretation, this amounts to a root-and-branch rejection of the idea of minimum core obligations, even as a tool for interpreting what counts as reasonable measures under progressive realization. Such an interpretation is encouraged by O’Regan J's claims that Grootboom 'rejected the argument that the social and economic rights in our Constitution contain a minimum core which the state is obliged to furnish, the content of which should be determined by the courts' and that the Court in TAC No 2 'refused to accept that section 27 of the Constitution had a minimum core content. ${ }^{57}$ However, it is arguable that the case still fits

50 Soobramoney $v$ Minister of Health KwaZulu Natal 1997 (12) BCLR 1696 (the Court found the state has a constitutional obligation to provide health care, as well as sufficient food, water and social security but dismissed applicant's claim for regular kidney dialysis). 51 TAC No.2, paras 37-38, see also paras. 93-114. Along similar lines, see Mazibuko and Others $v$ City of Johannesburg 20104 SA 1 (CC), para 61 (case concerned the right to access to water sufficient for a dignified life; Court rejected applicant's claim that it should 'adopt a quantified standard determining the content of the right not merely its minimum core').

52 TAC No.2, para. 125.

53 TAC No.2, para. 125.

${ }_{54}$ Mazibuko and Others $v$ City of Johannesburg 20104 SA 1 (CC).

${ }_{55}$ Mazibuko and Others $v$ City of Johannesburg 20104 SA 1 (CC), para 56.

56 Mazibuko and Others $v$ City of Johannesburg 20104 SA 1 (CC), para 59. 
with the analysis offered above of TAC No 2, especially if we focus on the following key passage regarding when the test of reasonableness will be failed:

[T] he positive obligations imposed upon government by the social and economic rights in our Constitution will be enforced by courts in at least the following ways. If government takes no steps to realise the rights, the courts will require government to take steps. If government's adopted measures are unreasonable, the courts will similarly require that they be reviewed so as to meet the constitutional standard of reasonableness. From Grootboom it is clear that a measure will be unreasonable if it makes no provision for those most desperately in need. If government adopts a policy with unreasonable limitations or exclusions as described in Treatment Action Campaign (No 2), the court may order that those be removed. Finally, the obligation of progressive realization imposes a duty upon government continually to review its policies to ensure that the achievement of the right is progressively realised. ${ }^{58}$

What we find in the South African jurisprudence is a combination of three elements: (a) a denial that there is a justiciable claim to be immediately furnished with the content of one's socio-economic rights, whether that content features in the minimum core obligations or not; (b) an acknowledgement that the doctrine of minimum core may nonetheless be relevant to, if not be determinative of, applications of the all-things-considered test of reasonableness in realizing the relevant rights; and (c) the failure by the Court explicitly to articulate, or even rely upon, specific minimum core obligations in reaching its decision. Notwithstanding (c), however, it is possible that the minimum core doctrine may be implicit in some of the decisions - especially those that involve fulfilment of the right to health insofar as it addresses urgent needs (Grootboom), as well as various forms of unjustified exclusions (TAC No 2), which are perhaps two of the most fertile domains for finding minimum core obligations. Some questions, arise, however, as to what exactly the idea of 'minimum core' is taken to mean in the South African jurisprudence. The TAC No. 2 case lends itself to an analysis in terms of obligations of immediate effect. But the Grootboom judgment is less perspicuous. At one point, Yacoob J refers to the minimum core as 'the floor beneath which the conduct of the state must not drop if there is to be compliance with the obligation'. ${ }^{59}$ Unless he was intending to impute to minimum core obligations the quality of non-derogability, this seems an unhappy formulation, since it presumably applies to the entirety of the obligations associated with any given human right, rather than to just a sub-set that constitutes the minimum core. On the issue of whether minimum core is an invariant or variable standard, Grootboom seemed to appeal to the latter understanding as part of an explanation why the Court may not be well-placed to identify minimum core obligations. Yacoob J contrasted the Court's position with that of the UN Committee on Economic, Social and Cultural Rights:

It is not possible to determine the minimum threshold for the progressive realization of the right to access to adequate housing without first identifying the needs and opportunities for the enjoyment of such a right. These will vary according to factors such as income, unemployment, availability of land and poverty. The differences between city and rural communities will also determine the needs and opportunities for the enjoyment of this right. Variations ultimately depend on the economic and social history and circumstances of a country. All this illustrates the complexity of the task of determining a minimum core obligation for the progressive realization of the right of access to adequate housing without having the requisite information on the needs and the opportunities for the enjoyment of this right. The committee developed the concept of minimum core over many years of examining reports by reporting states. This Court does not have comparable information. ${ }^{60}$

It is one thing to claim that the Committee might have more information than a court that bears on determining the content of minimum core obligations. But this passage seems to go further in implying that the minimum core will vary from state to state, and perhaps even within a given state, depending on the contextual factors it enumerates. This suggests a mismatch between the minimum core doctrine in international legal doctrine, which plausibly refers to a globally invariant standard, and that in the South African jurisprudence. If, however, the latter interpretation also appeals to a globally invariant standard, then the problems

57 Mazibuko and Others $v$ City of Johannesburg 20104 SA 1 (CC) paras 53-54

${ }_{58}$ Mazibuko and Others $v$ City of Johannesburg 20104 SA 1 (CC), para 67.

59 Government of the Republic of South Africa \&Others $v$ Grootboom and others para 31 .

${ }^{60}$ Government of the Republic of South Africa \&Others $v$ Grootboom and others para 32 . 
of information are correspondingly mitigated. Recall, in any case, the point made in the Framework Report: both the immediate obligations that apply invariantly across all states and those that apply within any given state in line with its level of resources are important standards within international human rights law. However, 'minimum core' in the international context is most plausibly taken to refer to the former. And with the recent South African ratification of the IESCR, and the requirement under s.39(1) of the Constitution to consider international law as an interpretative tool in relation to the Bill of Rights, one might suppose that there is added interpretative pressure to interpret the 'minimum core' idea in South African jurisprudence as at least incorporating an invariant component.

\section{Colombia}

The Colombian Constitutional Court stands out as having developed a body of jurisprudence on economic, social and cultural rights -including the right to health - that is widely regarded as among the most progressive in the world. Although the right to health is not explicitly set out in the Constitution, it is of significance - especially in relation to the doctrine of minimum core obligations - that Colombia is a state party to the ICESCR. This gives the Covenant special status under the Colombian Constitution: 'International treaties and agreements ratified by Congress that recognize human rights and prohibit limitation in states of emergency have domestic priority' and '[t]he rights and duties mentioned in this Charter shall be interpreted in accordance with international treaties on human rights ratified by Colombia' (Article 93, paras. 1 and 2).

Since the 1990s, Colombia has made significant progress in securing the human right to health, often outpacing more developed nations. For example, the number of people in the lowest income quintile with access to health care not paid out of pocket jumped from less than 5\% in 1993 to over $85 \%$ in $2011 .{ }^{61}$ However, serious problems remain, including health disparities that track divisions of race, ethnicity, class, as well as between urban- and rural-dwellers. Some of these problems were exacerbated by the exceptional levels of litigation for the protection of constitutional rights in relation to health matters $(674,612$ such actions between 1999 and 2008). The Court's landmark judgment T-760/08 sought to improve overall rights compliance of the health care system and thereby stem the extraordinarily levels of litigation. ${ }^{62}$

In Judgment T-760/08 (2008), the Colombia Constitutional Court considered twenty-two actions of tutela (a 'protection writ' designed to protect fundamental rights, analogous to the amparo) relating to regulatory failures in the health care system. The fundamental question was whether these failures constituted a violation of the constitutional obligation to respect, protect, and fulfill the right to health and its effective enjoyment. The Court ordered a structural reorganization of the entire Colombian healthcare system, including the provision of essential medicines and health services to those who could not afford them. In justifying its intervention, the Court made a number of points relevant to the right to health and its associated minimum core obligations. First, the Court affirmed the existence of a 'constitutional right to be guaranteed access to the required services, that is, those services that are indispensable to maintain one's health when one's life, personal integrity or dignity is seriously threatened'. ${ }^{63}$ Second, the Court clearly distinguished the existence of this fundamental right from the question of the extent to which it is susceptible to protection through the tutela: 'the possibility of enforcing the obligations derived from a fundamental right, and the merits of doing so through the action of tutela, are distinct and separable issues' ${ }^{64}$ Third, the obligations associated with the right to health included are not limited to entitlements under the Obligatory Health Plan (POS). Instead, the right to health will also be violated when:

(i) the lack of the medical service violates or threatens the rights to life and personal integrity of those who need it, (ii) the service cannot be replaced by another that is included in the obligatory plan, (iii) the patient can not afford to directly pay for the service, nor the amounts that the health care provider is legally authorized to charge, and can not access the service by another different plan, and (iv) the medical service has been ordered by a doctor attached to the entity charged with ensuring the provision of the service to those requesting it. ${ }^{65}$

Fourth, the scope of the tutela includes obligations arising from the right to health 'even though they had a programmatic character and realization was progressive. ${ }^{66}$ Fifth, and most importantly, the Court endorsed the idea of minimum core

\footnotetext{
${ }_{61}$ Julian Urrutia, 'A fundamental right to health? So they're saying in Colombia...', Bill of Health Sept 13, 2013.

62 For a general discussion, see Alica Ely Yamin and Oscar Parra-Vera, 'Judicial Protection of the Right to Health in Colombia: From Social Demands to Individual Claims to Public Debates', Hastings Int'l \& Comp. L. Rev. 33 (2010): 101-129, at 101.

63 Judgment T-760/08 (2008), 4.4.1.

64 Judgment T-760/08 (2008), 3.2.2.

65 Judgment T-760/08 (2008), 4.4.3. 66 Judgment T-760/08 (2008), 3.2.4.
} 
obligations, understood as obligations of immediate effect and hence not subject to progressive realization. These too can fall within the scope of the protection afforded by the tutela:

\begin{abstract}
The Court does not find that the positive aspects of a law are always subject to a gradual and progressive protection. "When the failure to meet the minimum obligations places the holder of the right to health in imminent danger of unreasonable harm", such holder can immediately claim the judicial protection of the law. The approach suggested by the case law to determine when such a situation applies is one of urgency. ${ }^{67}$
\end{abstract}

Elaborating on obligations of immediate effect, the Court argued that they generally fall into one of two categories: (i) those that are straightforward and can be realized without deploying additional resources, and (ii) those that required immediate action in virtue of the severity and urgency of their subject-matter:

Some of the obligations that arise from a fundamental right and that have a programmatic character, are to be carried out immediately, either because they require a simple action of the State, which does not require additional resources (e.g., the obligation to provide information of their rights to patients before undergoing a medical treatment, or because, despite the need to mobilize resources required, the severity and urgency of the case requires an immediate state action (e.g., the obligation to take appropriate steps to ensure health care for every baby during his or her first year of life - art. 50, Political Constitution). Other obligations of programmatic character derived from a fundamental right are carried our progressively, because of the complexity of the actions and resources required to guarantee the effective enjoyment of these protective aspects of the right. ${ }^{68}$

However, the Court did not give anything like a comprehensive specification of the scope and content of the obligations arising from the right to health, including minimum core obligations, nor of the generality of the obligations associated with the right, apart from noting some established exclusions, such as cosmetic treatments and surgeries, fertility treatments, alcoholic rehabilitation (3.52). Instead, as Yamin and Parra-Vera have observed:

"the Court called for a broad public dialogue about the content of the new POS - any by extension the dimensions of the right to healthcare in Colombia.
The Court did not assume it knew best what benefits should be included under the POS, nor did it set out ethical grounds for making those determinations... The Court did stipulate that the process might well result in exclusions from the current POS, and that it would prima facie consider that such elimination was not regressive so long as each elimination was justified" ${ }^{70}$

This court-initiated dialogue played a role in the eventual adoption, in 2015, of a new Statutory Law on Health grounded in the right to health. ${ }^{71}$ This development illustrates the potentially productive synergy between the judiciary and the legislature in the formulation of the content of the minimum core obligations associated with the right to health.

It is not possible to enter into the same level of detail with respect to other state jurisdictions; however, below is a sampling of a few others.

\section{Argentina}

An Argentinian appeals court, the Cámara de Apelaciones en lo Contencioso Administrativo y Tributario (Ciudad Autónoma de Buenos Aires), recognized in the case of Asociación Civil por la Igualdad y la Justicia c/ Gobierno de la Ciudad de Buenos Aires (2007), that the state had a minimum core obligation to provide for essential amounts of potable water, an obligation that applies even in emergency situations and is not subject to merely progressive realization.

\section{India}

In Paschim Banga Khet Mazdoor Samity \& Ors v. State of West Bengal \& Anor, ${ }^{72}$ the Supreme Court of India was confronted with the case of a man who was refused emergency treatment at a series of state-run hospitals for lack of adequate space or medical capabilities. In finding that the man's right to life was violated, the Court established a right to access to adequate emergency medical facilities, a right whose lack of enforcement cannot be justified by a lack of financial means:

\footnotetext{
67 Judgment T-760/08 (2008), 3.3.2.

68 Judgment T-760/08 (2008), 3.3.6.

69 Judgment T-760/08 (2008), 3.5.2.

70 Alica Ely Yamin and Oscar Parra-Vera, 'Judicial Protection of the Right to Health in Colombia: From Social Demands to Individual Claims to Public Debates', p.118.

${ }^{71}$ Ley Estatutaria 1751 Por Medio de la Cual se Regula el Derecho Fundamental a la Salud y se Dictan Otras Disposiiones, D.O. 49427 (16 Feb. 2015).

72 Paschim Banga Khet Madoor Samity \& Ors $v$. State of West Bengal \& Anor (1996) AIR SC 2426.
} 
'It is no doubt true that financial resources are needed for providing these facilities. But at the same time it cannot be ignored that it is the constitutional obligation of the State to provide adequate medical services to the people. Whatever is necessary for this purpose has to be done. ${ }^{73}$

The right to access to essential medicines has also been an area of core minimum obligations that has proved fertile ground for courts. In Mohd. Ahmed v. Union of India \& Ors., the High Court of Delhi at New Delhi addressed the issue of 'whether the Indian Government owes a constitutional duty to provide free medical treatment to the petitioner suffering from a rare and a chronic disease, even though the treatment is expensive and recurring. In answering this question positively, the Court relied expressly on the idea of core obligations as developed in General Comments No. 3 and 14 of the UN Committee on Economic, Social and Cultural Rights, and emphasized the non-derogability of the obligation to provide access to essential medicines: 'This Court is of the view that core obligations under the right to health are non-derogable. . . Government cannot cite financial crunch as a reason not to fulfil its obligation to ensure access of medicines or to adopt a plan to treat rare diseases.' ${ }^{75}$

\section{Brazil}

Right-to-health litigation in Brazil has mainly focused on the right to essential medicines, with the courts ordering the provision of such medicines in hundreds of cases. ${ }^{76}$ The starting point for these efforts was the successful fight to compel the provision of HIV/AIDS drugs in the 1990s. Since then, efforts to compel the provision of other essential medicines have exploded in number. Two cases can serve as illustrations of this trend. In RE 242.859/RS, 29.6.1999 the claimant sought free provision of medication for HIV. The state argued that such provision was a matter for the legislative and executive branches of government. The Brazilian Supreme Federal Tribunal (SFT) upheld the Lower Court's decision that the medication should be provided. The judgment is significant because the SFT made no reference to the limited availability of resources and seemed to describe a non-derogable obligation on the part of the state to provide all medication needed by all individuals that cannot afford them. By contrast RE/AgR 271.286-RS,12.9.2000, with similar facts, does not dismiss the relevance of resource constraints. However, it describes them as a 'secondary financial interest of the state', which cannot restrict the right to health. In the words of the judge:

Between protecting the inviolable rights to life and health, which are subjective inalienable rights guaranteed to everyone by the Constitution itself (art. 5, caput and art. 196), and the upholding, against this fundamental prerogative, of a financial and secondary interest of the State, I believe that - once this dilemma occurs -ethical-juridical reasons compel the judge to only one possible solution: that which furthers the respect of life and human health ...

\section{Italy}

Italy's Supreme Court of Cassation has affirmed a 'right to survival' entitling people to help themselves to small amounts of food belonging to others, e.g. grocery stores, 'in the face of an immediate and essential need for nourishment, acting therefore in a state of necessity'. The clear implication of the judgment is that people have a right to be immediately provided with the daily amount of food necessary for survival, and in the face of non-provision, may take unilateral steps to procure such food, including through actions that would ordinarily constitute the crime of theft. ${ }^{77}$ Insofar as the minimum core obligations associated with the right to health include an obligation to provide the minimum food needed for survival, this decision may be interpreted as an acknowledgment of that obligation.

\section{Germany}

The German Federal Constitutional Court has recognized a right to the guarantee of a subsistence minimum consistent with human dignity (Article 1.1 of the Basic Law) and the principle of social welfare (Article 20.1). This right secure for all persons the material prerequisites indispensable for his or her physical existence and for a minimum of participation in social, cultural and political life. ${ }^{78}$ However, it did

\footnotetext{
73 Paschim Banga Khet Madoor Samity \& Ors $v$. State of West Bengal \& Anor, para. 16

${ }^{74}$ Mohd. Ahmed v. Union of India \& Ors. W.P. 7279/2013 (2014), para. 46.

75 Mohd. Ahmed v. Union of India \& Ors. W.P. 7279/2013 (2014), paras. 43, 67 and 69 .

${ }^{76}$ For a comparative overview, see O. Ferraz, 'Between Abdication and Usurpation: Social Rights in the Courts of Brazil, India and South Africa', in O. Vilhena, U. Baxi, and F. Viljoen, Transformative Constitutionalism: Comparing the Apex Courts of Brazil, India and South Africa (2013).

77 http://www.bbc.co.uk/news/world-europe-36190557

78 Judgement of 9 February 2010, 1 BvL 1/09. http://www.bundesverfassungsgericht.de/SharedDocs/Entscheidungen/EN/2010/02/ ls20100209_1bvl000109en.html
} 
not refer explicitly to the idea of 'minimum core obligations' in articulating the content of this right.

\section{Conclusion}

An inevitably selective review of state law and practice reveals considerable diversity. There is great variability as to whether the idea of minimum core obligations is invoked in national jurisprudence and, if it is, how it is understood, which obligations are counted as such, whether these obligations are non-derogable (and if not, in which circumstances they are defeated), and what forms of implementation and redress are in place, including whether or not they are justiciable. Regarding implementation and, in particular, justiciability, the legal situation in Colombia stands in strong contrast with that in South Africa insofar as the doctrine of minimum core is explicitly affirmed as playing a central role in specifying obligations that can be directly claimable through the courts. By contrast, the South African court exhibits a far more cautious approach to the notion of minimum core obligations. Interestingly, however, the Colombian jurisprudence also displays a sensitivity to the limited capabilities of the judicial branch in specifying the content of minimum core and other obligations arising under the right to health. Hence Judgment T-760/08 left considerable scope for governmental discretion in achieving the specified goals, subject to certain procedural and other safeguards, and called for a 'broad public dialogue' on these obligations, the deliverances of which will also be implemented through the executive and legislative branches of government.

The comparison between the jurisdictions suggests six major conclusions: (a) even when a minimum core obligation exists under the right to health, it may nonetheless be derogable in the light of resource limitations; (b) that the existence of minimum core obligations is a separate matter from the question of how best they are best implemented, in particular, the question of the nature of the role, if any, that should be accorded to courts in defining and enforcing them (c) that the modes of judicial implementation are various, and are not limited to the case of individual claimants being able to enforce their right to their individual entitlements through the courts, (d) that courts may play an important role alongside other organs of the state in defining and enforcing minimum core obligations, (e) that the role of the respective organs of government in these processes may legitimately vary from one jurisdiction to another, depending on contextual factors, such as judicial traditions, the relative efficacy and legitimacy of various branches of government, and so on; and (f) that essential medicines (including antiretrovirals for HIV infection), non-discrimination, and access to minimum levels of food and water figure prominently among obligations of immediate effect in states where the notion of minimum core obligations is recognized 


\section{Minumum Core Obligations, Development, and Indicators}

\section{Human Rights and Development}

How does the discourse of human rights relate to that of the post-2015 development, especially as formulated in the Sustainable Developmental Goals (SGD)? That is a difficult question with many dimensions, ranging from the philosophical to the intensely practical. As argued in the Framework Report, human rights are integral components of the ends of sustainable development, but not exhaustive of them. Human rights are integral to sustainable development because they fix the extent to which all human beings have rights to - and others have obligations to furnish - certain important benefits, such as freedom of speech and movement, health care, work, non-discrimination and cultural and political participation. But human rights are non-exhaustive of the logic of development, because not all human interests that are the focus of development are protected by rights, while some legitimate developmental concerns (such as the preservation of species of flora and fauna) are not exclusively a matter of catering to human interests. On this view, therefore, the arguments of those who contend that we should abandon the discourse of human rights for that of development economics are profoundly mistaken. ${ }^{79}$ The idea that we must choose between human rights and development in policy-formation turns out to be a false one, since the latter inescapably embraces the former as a central component.

Unfortunately, however, the centrality of human rights to development, even when it is formally acknowledged, is often registered at a purely rhetorical level, and so fails to genuinely influence the formation and implementation of development policy. The point has been forcefully made by Alicia Ely Yamin in the context of the human right to health:
Although human rights rhetoric is increasingly invoked in relation to the SDG agenda, it often amounts to little more than rhetorical flourishes designed to make an impression at high-level meetings, like the dazzle of a firework that leaves no permanent structure behind. There is a significant danger that when reduced to such sloganeering, the aspirational language of human rights serves only to deodorize recycled forms of degradation that threaten to become embedded in the implementation of the SDGs, rather than forcing us to chart a new course to see real progress in the world. ${ }^{80}$

There are various reasons for this dismal state of affairs; some relate to unjustified intellectual or political resistance on the part of development economists to the encroachment of human rights concerns onto their field. But there are also causes arising from misunderstandings and errors propagated by human rights advocates, partly stemming from the fact that human rights thinking in the economic, social and cultural domain is still at a fairly rudimentary state of evolution. In particular, human rights advocates have not always done a good job of explaining the distinctive 'value added' of human rights approaches in contrast with ordinary cost-benefit analysis nor of disentangling human rights from certain dubious assumptions, such as that human rights exclusively bind states (statism) and ought always to be implemented via law that is enforceable by right-holders

79 E.g. E. Posner, The Twilight of Human Rights Law

80 Alicia Ely Yamin, 'Taking the Right to Health Seriously: Implications for Health Systems, Courts, and Achieving Universal Health Coverage', Human Rights Quarterly 39 (2017): 341-68, p.343. 
through the courts (legalism). In the Framework Report, an account of human rights law was presented that sought to avoid both of these errors. On the one hand, human rights discourse is distinctive in that it ultimately concerns not mere interests to be factored into a cost-benefit analysis, but rather universal rights that impose obligations on others and which are, therefore, not readily susceptible to trade-offs against countervailing considerations. In this connection, what is called for is not a one-way learning process between human rights lawyers and development economists: proper attention to the obligations associated with human rights demands careful scrutiny of their feasibility, and lawyers have much to learn from economists on the issue of cost-effectiveness. On the other hand, it is an open question to what extent human rights, considered ultimately as moral norms, are best realised through the imposition of duties on the state or by means of judicially enforceable legal entitlements.

At the most fundamental level, the main contribution that the MCD can make is in helping to address issues of priority-setting within the diverse range of goals encompassed by sustainable development. Human rights, as we have seen, differ from interests in being inherently resistant to trade-offs, even if not entirely resistant, due to the fact that they have associated obligations, and it belongs to the nature of an obligation to be a kind of reason with which non-compliance is not only morally wrong but which is not regularly overridden by countervailing considerations. To this extent, rights take priority, ceteris paribus, over nonrights-based considerations. But the MCD helps us address a priority question that arises within the domain of economic, social and cultural rights, i.e. how to sequence temporally compliance with rights in cases in which resource limitations prevent them being all complied with immediately. In so doing, the MCD provides an important principled basis for prioritizing compliance with some obligations of economic, social and cultural rights over others - for example, prioritizing the delivery of primary health care, or essential drugs, over tertiary health care, or non-essential drugs, of non-discrimination in the delivery of medical services over marginal increases in the quality of those services beyond the 'minimum core', and so on.

In what follows, I will briefly consider the ways in which the minimum core obligations associated with the human rights to health may profitably interact with the SDG agenda, focusing on two issues (1) Universal Health Coverage (UHC) and (2) indicators for the human right to health, especially the minimum core obligations encompassed within UHC.

\section{Universal Health Care and the Minimum Core of the Right to Health}

There are numerous formulations of what is encompassed by UHC. For present purposes, I take as canonical the formulation in the UN General Assembly's Resolution Transforming Our World: the 2030 Agenda for Sustainable Development. ${ }^{81}$ This articulates 17 multi-part Sustainable Development Goals (SDGs), the third of which concerns ensuring healthy lives and promoting well-being for all at all ages. Sub-goal 3.8 relates to UHC:

Achieve universal health coverage, including financial risk protection, access to quality essential healthcare services and access to safe, effective, quality and affordable essential medicines and vaccines for all. ${ }^{82}$

Although the entire SDG agenda is presented as grounded in the Universal Declaration of Human Rights and other human rights instruments, it makes no specific mention of the human right to health, nor of minimum core obligations associated with that or any other right. Nonetheless, an intimate connection has been affirmed between UHC, in particular, and human rights. The WHO sees UHC as a 'practical expression of health equity and the right to health'. ${ }^{83}$ As Lisa Forman and co-authors have observed: "This emphasis

81 Tranforming Our World: The 2030 Agenda for Sustainable Development, G.A. Res. 70/1, U.N. GAOR, 7th Sess., Agenda Items 15 and 116, UN Doc. A/RES/70/1 (21 Oct. 2015).

82 Other definitions include: 'access to key promotive, preventive, curative and rehabilitative health interventions for all at an affordable cost, thereby achieving equity in access': World Health Assembly, Sustainable Health Financing, Universal Coverage and Social Health Insurance, WHO Doc. WHA58.33 (2005); “all people receiving quality health services that meet their needs without exposing them to financial hardship in pay for" those services: T. Ottersen and O. Norheim, et. al., World Health Organization, Making Fair Choices on the Path to Universal Health Coverage 1 (2014); and, seemingly more expansively, as including including 'promotion, prevention, treatment, rehabilitation and palliation', including e.g. adequate sanitation and non-use of tobacco, adequate water sources: WHO and World Bank Group, Monitoring Progress Towards Universal Health Coverage at Country and Global Levels 1, 5 (2014).

83 WHO, Positioning Health in the post-2015 development agenda. WHO Discussion Paper (Geneva: UN, 2012). See also WHO, The World Health Report 2013: Research for Universal Health Coverage (Geneva: WHO, 2013), p.3; and UN GA (Global health and foreign policy, UN Doc. A/67/L.36, pp.944-47): '[a]ll people have access, without discrimination, to nationally determined sets of the needed promotive, curative and rehabilitative basic health services, while ensuring that the use of these services does not expose the users to financial hardship, with a special emphasis on the poor, vulnerable and marginalized segments of the population', para 10. 
on non-discriminatory access to basic health services and essential medicines with a special focus on the poor, vulnerable, and marginalized indicates a clear commitment to human rights principles". ${ }^{84}$

Unfortunately, beyond this general connection, what exact relationship obtains between UHC and the human right to health (or, more specifically, its minimum core obligations) remains obscure. Is UHC, as a whole, a demand of the right to health, or only partially so? And, insofar as it is such a demand, to what extent, if any, does it embody minimum core obligations that are to be complied with immediately, and to what extent is it open to progressive realization in the case of resource limitations? On the expansive understanding of the minimum core obligations (supplemented by obligations of "comparable priority") outlined in General Comment 14, UHC would appear to be a minimum core obligation. But, as we saw, that interpretation is potentially over-demanding in various ways. However, even on the more circumspect interpretation of the minimum core obligations of the right to health recommended in section II above, it would seem that most, if not all, of the elements of UHC would count as minimum core obligations. This is compatible with the UHC encompassing non-core obligations as well, and with the minimum core obligations covering matters (e.g. minimum food and water) beyond the provision of UHC. ${ }^{85}$

We can now consider two objections: 1) Is UHC, or substantial elements of it, feasible as a minimum core obligation to be immediately complied with by all states? and 2) Even if it is feasible, how can it assist with the difficuly problems of priority-setting and trade-offs involved in health policy? I address these questions in turn below.

Perhaps the most fundamental and recurrent question that arises regarding UHC is whether it is feasible as a genuinely universal demand on all states, despite resource variations amongst them, and - to the extent that it embodies minimum core obligations, a demand that can feasibly be imposed as an obligation of immediate effect. Do sufficient resources exist, in a sufficient number of countries, for UHC to be possible to comply with as a minimum core obligation? And even if delivery of UHC is possible, would it be unduly burdensome to impose such an obligation? In this regard, it is important to take note of studies from a number of poor countries, e.g. China, Sri Lanka, Costa Rica, Cuba, Indian state of Kerala, Thailand, Rwanda, Brazil, Mexico, showing that basic healthcare for all can be provided at a good level at very low cost. As Amartya Sen has argued recently:

The critical ingredients of success that have emerged from these studies appear to include a firm political commitment to the provision of universal healthcare, running workable elementary healthcare and preventive services covering as much of the population as possible, paying serious attention to good administration in healthcare and ancillary public services and arranging effective school education for all. Perhaps most importantly, it means involving women in the delivery of health and education in a much larger way than is usual in the developing world. ${ }^{86}$

Among the reasons why it is false to conclude that poor countries cannot in general feasibly deliver UHC, Sen lists the following: (a) basic level healthcare is a very labour-intensive activity, and in a poor country wages tend to be low; (b) whatever level of healthcare is affordable within a state's resource constraints can in general be more effectively and equitably provided through UHC; (c) many health services are non-excludable, collective goods, that are not efficiently allocated by a pure market system; and (d) UHC is better at stemming the spread of infectious diseases and reduces overall costs through improved epidemiological care. Sen concludes with an eloquent call for immediate compliance with UHC, a call that resonates with the idea that it is, at least to a very large part, a minimum core obligation associated with the human right to health:

The case for UHC is often underestimated because of inadequate appreciation of what well-organised and affordable healthcare for all can do to enrich

84 L. Forman, C. Beiersmann, C.E. Brolan, M. McKee, R. Hammonds and G. Ooms, 'What Do Core Obligations Under the Right to Health Bring to Universal Health Coverage?', Health and Human Rights Journal 18 (2016), p.3.

85 It is hard to pin down the precise content of the minimum core obligations of the right to health encompassed within UHC, partly because the normative content of both of these ideas is far from widely agreed-upon at the level of detail. However, the article by Lisa Forman and co-authors explores the relationship between minimum core obligations of the right to health and the 'essential health care and medicines' aspect of SDG 3.8: L. Forman, C. Beiersmann, C.E. Brolan, M. McKee, R. Hammonds and G. Ooms, 'What Do Core Obligations Under the Right to Health Bring to Universal Health Coverage?', Health and Human Rights Journal 18 (2016), p.5. The authors adopt a somewhat overly strict interpretation of the minimum core obligations in General Comment 14, insofar as they exclude the obligations identified as being of 'comparable priority'. However, they rightly stress the importance of non-discrimination for what, as well as who, is covered by UHC, pointing out, inter alia, that '[a] pressing question for UHC will be the extent to which non-nationals, particularly those lacking documents, are included, given how some high-income countries have excluded certain classes of migrants from health care in the past', p.9.

86 A. Sen, 'Universal healthcare: the affordable Dream', Guardian, 6th January, 2015 https://www.theguardian.com/society/2015/ jan/06/-sp-universal-healthcare-the-affordable-dream-amartya-sen 
and enhance human lives. It is one thing to accept that the world may not have the resources and the dexterity at this moment to provide the finest of medical care to all but that is not a reason for eliminating our search for ways of proceeding towards just that, nor a ground for refusing to provide whatever can be easily provided right now for all.

If we accept that UHC, to a significant degree, incorporates feasible minimum core obligations associated with the right to health, we might then ask the second question: what is the value of identifying such obligations? In line with the General Report, the answer lies in their role in helping address questions of priority-setting and trade-offs. The role that minimum core obligations can play in this way in fairly progressively realizing the SDG agenda of UHC can be underscored by considering Making Fair Choices on the Path to Universal Health Coverage, the Final Report of the WHO Consultative Group on Equity and Universal Health Coverage. ${ }^{87}$ The consultative group consisted of philosophers, economists, health policy experts and clinical doctors representing thirteen nationalities. The Report offers guidance to states in addressing the challenges of achieving UHC in circumstances in which it is not possible to do so immediately for all of its elements. Guidance is offered on two crucial, related matters: (a) which elements of UHC to prioritize when seeking to achieve it over time and (b) which trade-offs would normally be impermissible when seeking to realize UHC. Although the MCD is highly relevant to both of these matters, since obligations of immediate effect should, ceteris paribus, be realized before other obligations and goals, and should not ordinarily be traded off against them, the notion of minimum core obligations unfortunately does not explicitly figure in the Report, despite the latter's repeated use of the idea of 'progressively realizing' UHC. Nonetheless, the MCD potentially has considerable importance as a key means of fleshing out and putting into effect the consultative groups' recommendations.

Regarding (a), the Report identifies three main dimensions along which a country must advance in order to achieve UHC: (i) expand priority services, (ii) include more people, and (iii) reduce out-of-pocket payments. This raises a series of questions, including which services to expand first, whom to include first within the scope of coverage, and how to move from out-of-pocket payments towards prepayment. ${ }^{88}$ Regarding the first question, the Report recommends categorizing services into priority classes, using criteria such as cost-effectiveness, priority to the worse off, and financial risk protection. The obvious thing here is that the MCD is another basis for defining priority services, one that itself often reflects precisely the criteria that the Report identifies as salient. To this extent, the MCD and the Report's proposals can be mutually reinforcing in identifying priority services. Regarding the second and third questions, the Report recommends expanding high priority services to everyone - with a special focus on ensuring that disadvantaged groups, such as low income groups and rural populations, are included - by eliminating out-of-pocket payments while increasing mandatory, progressive prepayment though pooling funds. Here again, we see a missed connection which the MCD, which in most formulations prominently incorporates strong norms of non-discrimination and a special concern for the most vulnerable.

Regarding (b), the identification of generally impermissible trade-offs in the kinds of health services provided, the authors of the Report again make a number of plausible recommendations that resonate with the spirit of the MCD: 'One [normally impermissible trade-off] would be to expand coverage for low- or medium- priority services before near-universal coverage exists for high-priority services. For example, 'it would normally be unacceptable to expand coverage for coronary bypass surgery before securing universal coverage for skilled birth attendance and services for easily preventable or easily treatable, fatal childhood diseases' ${ }^{89}$ Again, it would seem that many, although certainly not all, of the generally prohibited trade-offs could be readily understood in terms of the operation of minimum core obligations, which must be realized immediately, trumping those obligations which are non-core. Indeed, the MCD potentially offers guidance regarding how UHC is to be traded-off against other SGDs, including the other nine health-related targets associated with the SDG 3. So, despite the fact that the WHO's Report shows a laudably keen awareness of the importance of a human rights framework for the progressive realization of the UHC, including by ensuring accountable and participatory health policy, ${ }^{90}$ it misses the important potential substantive connection between its recommendations and the doctrine of the MCD, to the detriment of both.

In short, a properly developed MCD can make a vital contribution to giving substance to the priority-setting and trade-off recommendations in the Report. Of course, the topics of priority-setting and trade-offs in health policy go

\footnotetext{
87 Making Fair Choices on the Path to Universal Health Coverage, the Final Report of the WHO Consultative Group on Equity and Universal Health Coverage. Geneva: World Health Organization, 2014. Available from: http://www.who.int/choice/documents/ making_fair_choices/en

${ }_{88}$ Making Fair Choices on the Path to Universal Health Coverage, ch.6. 89 Making Fair Choices on the Path to Universal Health Coverage, p.38. 90 Making Fair Choices on the Path to Universal Health Coverage, ch.7.
} 
beyond the idea of minimum core obligations, since it will sometimes be necessary to address them exclusively in relation to competing non-core health obligations. But arguably, the most urgent issues of priority-setting will involve just those obligations under the right to health that must be immediately fulfilled by all states.

\section{Indicators}

An important part of the SDG agenda has been the formulation of measurable and accurate indicators for UHC to monitor the level of success in achieving any given SDG. As discussed in the Framework Report, indicators are important tools for assessing the extent to which a policy goal is being realized, although they bring with them a host of problems, such as the tendency for the indicator to upstage the goal itself in the decision-making of states or, more insidiously, for the indicator to be used to shape illegitimately our understanding of the goal, downplaying those aspects of it that may be very important yet not readily amenable to measurement. As Devi Sridhar and co-authors have pointed out, there are in addition three other significant problems in fashioning indicators for the SDG goal of UHC: (a) the availability of adequate data, especially in the case of developing countries; (b) the universality of targets (a goal advanced as universal may not fit with the circumstances or priorities of all states); and (c) the adaptation of global goals to local populations (some indicators universally relevant, e.g. child mortality, whereas others have more restricted relevance, e.g. mortality from malaria)..$^{91}$

The United Nations Statistical Commission has established an Inter-Agency Expert Group on SDG indicators (IAEG-SDGs) to propose indicators for each SDG target. ${ }^{92}$ The IAEG-SDGs began by proposing two indicators: one to monitor tracer interventions (e.g. complete childhood immunization, antiretroviral therapy, skilled birth attendance) and the other to monitor the proportion of a population protected from catastrophic or impoverishing out-of-pocket health expenditures. ${ }^{93}$ Uniquely among the indicators formulated by the IAEG-SDGs team, these two did not attract general agreement and were found to require further examination and development. More recently, the second indicator has been replaced by one that monitors the number of individuals per 1,000 population covered by health insurance or a public health system. ${ }^{94}$ The new indicator has been criticized on the basis of what are essentially human rights grounds: by focusing on aggregate outcomes it overlooks the kind the devastating impact on individual lives captured by the former indicator.
The first indicator, relating to tracer interventions, is further specified in various domains of promotion, prevention, and treatment which will serve as global indicators that all countries are expected to implement. ${ }^{95}$ Moreover, countries are expected to develop their own indicators attuned to 'their level of development, epidemiological situation, health system and people's expectations' and that 'cover promotion, prevention, treatment, rehabilitation and palliation'. ${ }^{96}$ According to Lisa Forman and co-authors, these tracer interventions appear to be based largely on a WHO and World Bank publication which proposes selecting interventions according to the criteria of relevance, quality, and availability. For treatment service, for example, six indicators are specified: skilled birth attendance, antiretroviral therapy, tuberculosis case detection and treatment success (combined into a single indicator), hypertension treatment and diabetes treatment. ${ }^{97}$

Sridhar and associates have argued that the selection of indicators by the IAEG-SDGs team 'appears to be driven by the ease of measurement and availability of data rather than by any clear conceptual or ethical framework'. ${ }^{98}$ They propose an alternative approach focused on what data would

91 D. Sridhar, M. McKee, G.Ooms et al, 'Universal Health Coverage and the Right to Health: From Legal Principle to Post-2015 Indicators', International Journal of Health Services 45 (2015): 495-506. 92 This paragraph and the next follow closely the account given in L. Forman, C. Beiersmann, C.E. Brolan, M. McKee, R. Hammonds and G. Ooms, 'What Do Core Obligations Under the Right to Health Bring to Universal Health Coverage?', Health and Human Rights Journal 18 (2016), p.7.

${ }_{93}$ United Nations Statistics Division, Results of the list of indicators reviewed at the second IAEG-SDG meeting (November 2, 2015)

${ }_{94}$ United Nations Statistics Division, Provisional proposed tiers for global SDG indicators (March 24, 2016)

95 Inter-Agency Expert Group on SDG Indicators, Compilation of metadata for the proposed global indicators for the review of the 2030 Agenda for Sustainable Development (2016), p. 40. Available at http:// unstats.un.org/sdgs/files/metadata-compilation/Metadata-Goal-3.pdf 96 Id.

97 World Health Organization and World Bank Group, Monitoring progress towards universal health coverage at country and global levels: Framework, measures and targets (Geneva: World Health Organization, 2014), p. 5. The WHO report Making Fair Choices on the Path to Universal Health Coverage proposes four types of indicators by means of which UHC can be monitored and evaluated: indicators related to priority-setting processes and indicators of coverage, financial risk protection, and health outcomes, e.g. life expectancy, maternal mortality, stunting rates, etc. Moreover, it emphasizes that for the last three types of indicators, distribution across relevant groups (e.g. socio-economic, gender, area of living, etc) must be measured, not just average levels, p.50.

98 D. Sridhar, M. McKee, G.Ooms et al, 'Universal Health Coverage and the Right to Health: From Legal Principle to Post-2015 Indicators' Int J Health Serv. 2015;45(3):495-506. 
be necessary on a conception of UHC as grounded in the right to health. The ten indicators they propose in this vein are set out in the table below, with the concepts of minimum core obligations and progressive realization doing important work in specifying the underlying legal principle that the indicator is intended to capture:

\section{Indicator}

1 The existence of a legal mandate for $\mathrm{UHC}$ in the country

2 The extent of coverage in terms of depth (which services are covered)

3 The extent of coverage in terms of breadth (who is insured) with attention to equity

\section{Underlying legal principle}

Minimum core obligation/

progressive realization

Minimum core obligation/

progressive realization

Minimum core obligation/

progressive realization

Minimum core obligation/

progressive realization

(what proportion of cases are covered) with focus on reduction in share of outof-pocket payments for health care

5 The commitment of adequate resources to deliver UHC with focus on percentage of gross national product for healthcare

\begin{tabular}{llll}
\hline $\begin{array}{l}\text { Cost-effectiveness with attention to } \\
\text { equity }\end{array}$ & $\begin{array}{l}\text { Cost-effectiveness/ } \\
\text { nondiscrimination }\end{array}$ & $\begin{array}{l}\text { Data on use of branded/generic } \\
\text { drugs or high tech/basic } \\
\text { equipment }\end{array}$ \\
\hline $\begin{array}{l}\text { International assistance as a percentage } \\
\text { of GDP }\end{array}$ & Shared responsibility & OECD-DAC Database \\
\hline $\begin{array}{l}\text { Existence of an international } \\
\text { development policy explicitly including } \\
\text { specific provisions to promote and } \\
\text { protect the right to health }\end{array}$ & Shared responsibility & Extended SARA \\
\hline $\begin{array}{l}\text { SARA assessment on participatory } \\
\text { decision making }\end{array}$ & $\begin{array}{l}\text { Participatory decision making/ } \\
\text { nondiscrimination }\end{array}$ & Extended SARA \\
\hline $\begin{array}{l}\text { SARA assessment on prioritization of } \\
\text { marginalized groups }\end{array}$ & $\begin{array}{l}\text { Attention to vulnerable } \\
\text { and marginalized groups/ } \\
\text { nondiscrimination }\end{array}$ & \\
\hline
\end{tabular}

Abbreviations: GDP, Gross Domestic Product; SARA, Service Availability and Readiness Assessments; UHC, Universal Health Coverage; OECD-DAC, Organisation for Economic Co-operation and Development's (OECD) Development Assistance Committee.

The formulation of effective indicators for achieving UHC, and other aspects of the right to health, remains a vital work in progress. But if these indicators are genuinely to track compliance with the right to health, it is imperative that they are anchored in its normative content, including its minimum core obligations. The problem, however, is that more work needs to be done to fix that content, including settling on a list of minimum core obligations that satisfies the constraint of feasibility as obligations of immediate effect that are applicable to all states. In the absence of a more determinate content for the right to health and its minimum core obligations, there is a grave risk that any indicators chosen will illegitimately come to shape the very normative standard they are supposed to be monitoring. 



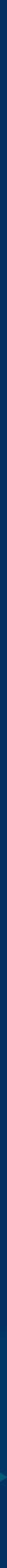

(4) THE WORLD BANK

Legal 